\title{
KONGRES WOLNOŚCI KULTURY I WOLNOŚĆ CZESŁAWA MIŁOSZA: REFLEKSJA O ZAANGAŻOWANIU I DRODZE DO PRAWDY W DOBIE ZIMNEJ WOJNY
}

\author{
Olga GLONDYS (Hiszpania)
}

W artykule tym naświetlimy problem zimnej wojny prowadzonej przez Stany Zjednoczone w domenie kultury, koncentrując się na działalności Kongresu Wolności Kultury (1950-1967). Jako casus studi obieramy postać największej polskiej gwiazdy tej organizacji, Czesława Miłosza ${ }^{1}$. W tym kontekście, przypatrzymy się walce pisarza o zachowanie prawa do wypowiadania własnej prawdy i do sprawiedliwego oddania „autentyczności” innych, oraz spróbujemy przybliżyć jak rozumiał kwestię zaangażowania. Artykuł powstał w oparciu o źródła książkowe i o niepublikowaną korespon-

\footnotetext{
${ }^{1}$ W Polsce o Kongresie Wolności Kultury pisał, przede wszystkim, Mirosław A. Supruniuk: Czestaw Miłosz i Kongres Wolności Kultury, Archiwum Emigracji. Studia - Szkice - Dokumenty 1998 z. 1, s. 95-102; „Wielkie pokuszenie”, albo zapomniany fragment „Zniewolonego umystu” Czestawa Mitosza, Archiwum Emigracji. Studia - Szkice - Dokumenty 2001 z. 4, s. 73-79; Przyjaciele wolności. Kongres Wolności Kultury i Polacy, Warszawa 2008. Do prac Kongresu odnieśli się też: P. Kłoczowski w przypisach do Chwil oderwanych K. A. Jeleńskiego (Gdańsk 2007, s. 520524); O. Glondys, „Zniewolony umyst” Czesława Miłosza i Kongres Wolności Kultury, Zeszyty Literackie $2009 \mathrm{nr}$ 105, s. 217-224. Warto wspomnieć też o publikacji w „Przeglądzie Politycznym” (1997, 1998) kilkunastu tekstów związanych z historią i interpretacją Kongresu Wolności Kultury, m.in.: D. Filar, Najpiękniejsza operacja CIA oraz wywiad z François Bondy'm przeprowadzony przez Izę Chruślińską (nr 33/34); P. Grémion, Berlin 1950 oraz J. Czapski, O zjednoczenie Europy (nr 35); Cz. Miłosz, Liberalna konspiracja (nr 36). Aktualną i wyczerpującą bibliografię zagraniczną podaje M. A. Supruniuk w: Przyjaciele wolności, s. 16.
} 
dencję, która znajduje się w Archiwum Kongresu Wolności Kultury, przechowywanym w Bibliotece Regenstein na Uniwersytecie Chicagowskim².

\section{WSCHÓD - MILOSZ — ZACHÓD: O WOLNOŚCI ZNIEWOLONEGO UMYSEU}

„Bestia wychodząca z morza” powaliła w ciągu tego stulecia swoich kolejnych przeciwników i rywali. Najpoważniejszym z rywali była Rosja sowiecka, ponieważ w tym zderzeniu chodziło nie tylko o militarną siłę, ale o model człowieka. Próba stworzenia „,nowego człowieka” wedle utopijnych zasad była gigantyczna, i ci, którzy ex post zbywają ją lekko, zdają się nie pojmować, o jaką stawkę toczyła się gra. Wygrał „stary człowiek" i przy pomocy mass mediów narzuca swój wzorzec całej planecie. Patrząc z perspektywy, należy w sferze kultury szukać przyczyn sowieckiej klęski ${ }^{3}$.

W ten sposób pisał Miłosz o zimnej wojnie w Abecadle. Uważał, że rozegrała się ona przede wszystkim w obszarze kultury i idei, i w dużo mniejszym stopniu w formie militarnej. W rzeczywistości, chodziło o zderzenie konkurujących ze sobą modeli wartości. Zarówno Stany Zjednoczone, jak i Związek Sowiecki, stworzyły własne retoryki (wokół ideałów wolności i pokoju) na potrzeby tego największego w historii konfliktu ideologicznego.

Powstanie Kominternu i CIA, w tym samym roku 1947, symbolicznie wyznaczyło początek tej rywalizacji, zakończonej demontażem muru berlińskiego pół wieku później. Oprócz działań oficjalnych, zarówno ze strony sowieckiej, jak i amerykańskiej, zimna wojna była prowadzona za pomocą „tajnych działań” (covert actions), których koszt w rozmaitych obszarach (kultura, edukacja, ruch związkowy, studencki, itp.) należy liczyć w miliardach dolarów.

Spośród wszystkich organizacji tajnie finansowanych przez CIA, Kongres Wolności Kultury był najważniejszą „organizacją fasadową” w domenie kultury i świata intelektualnego. W szczytowym momencie swojej działalności, posiadał biura w trzydziestu pięciu krajach i wydawał około dwudziestu prestiżowych gazet, które powiązane były z własnymi serwisami prasowymi. Od początku, był tajnie finansowany przez Office of Policy Coordination (OPC), komórkę CIA kierowaną przez Toma Bradena, której zadaniem była koordynacja antykomunistycznych inicjatyw intelektualistów. Nie wszystkie pieniądze Kongresu pochodziły z CIA (duża ich część trafiała także z prywatnych amerykańskich fundacji — Fundacji Forda, Rockefellera, itd.), nie zmienia to jednak sedna polemiki, czyli związków tej organizacji z Agencją, i wynikającej z tego problematyki etycznej, intelektualnej i politycznej.

Kongres Wolności Kultury powstał jako projekt czołowych amerykańskich architektów zimnej wojny, z zamiarem wsparcia tylko tych inicjatyw prywatnych, które uznane zostały za korzystne i pokrewne dla amerykańskich interesów politycznych i strategicznych. Zarazem z drugiej strony, jako naturalny wynik i konsolidacja inicja-

${ }^{2}$ Archiwum Generalne Kongresu Wolności Kultury przechowywane w sekcji Special Collections Biblioteki Regenstein Uniwersytetu Chicagowskiego w kolekcji International Association for Cultural Freedom (dalej: IACF); II (serie)/ 23 (box); f. 7 (folder). Cytowane tu listy J. Giedroyca i Cz. Miłosza pochodzą z: J. Giedroyc, Cz. Miłosz, Listy 1952-1963, oprac. i wstępem opatrzył M. Kornat, Warszawa 2008 („Archiwum Kultury”, t. 10); pochodzenie cytatów zaznaczono podając (w nawiasie) datę listu i numery stron. W cytowanych listach zachowano pisownię oryginału (podkreślenia autora). Wszystkie tłumaczenia pochodzą od autorki.

${ }^{3}$ Cz. Miłosz, Abecadło, Kraków 2001, s. 35. 
tyw, które zachodni intelektualiści antyfaszystowscy i antysowieccy podejmowali od lat z mniejszym lub większym powodzeniem. Po zwycięstwie aliantów nad Hitlerem, w którym tak wielki udział miała Armia Czerwona, ci którzy oskarżali Związek Radziecki o zbrodniczość i ludobójstwo byli osamotnieni i nie cieszyli się sympatią. W wyniszczonej wojną Europie nie tylko nie znajdowali posłuchu, ale także narażali się na prześladowania. W obliczu tego bojkotu pochodzącego z ważnych centrów europejskiej inteligencji, wielu antykomunistycznych intelektualistów przyjęło z wdzięcznością możliwości, które po 1947 r. zaoferowały im instytucje i organizacje finansowane przez Amerykanów.

Wielu intelektualistów, którzy aktywnie włączyli się do rywalizacji sowiecko-amerykańskiej na polu kultury i świata idei, przyjęło zarazem jako własną specyficzną retorykę tamtego czasu, w której walka o wolność kultury i o godność człowieka przybrała formę poparcia dla interesów politycznych i ideologicznych Stanów Zjednoczonych.

\section{Dziwny przypadek Czesława Miłosza}

Była wiosna 1951 r. Czesław Miłosz właśnie zerwał z Warszawą i ukrywał się w Maison-Laffitte, korzystając z gościny Jerzego Giedroycia i zespołu „Kultury”, którzy pomogli mu także nawiązać współpracę z Kongresem Wolności Kultury ${ }^{4}$. Oczekując na wizę do Stanów Zjednoczonych, Miłosz rozpoczął pracę nad Zniewolonym umystem oraz publikację tekstów w kongresowych czasopismach („Preuves”, „Encounter”, „Tempo Presente”, „Der Monat”, „Cuadernos”, „The Twentieth Century”), za które dostawał dość wysokie honoraria. Pisarz uzyskał także finansową pomoc od Fund for Intellectual Freedom Arthura Koestlera, oraz, także za pośrednictwem Kongresu, stypendium od amerykańskiej instytucji (która także była powiązana z CIA) International Rescue Committee. W 1953 r., razem z Józefem Czapskim, Józefem Wittlinem i Mirceą Eliadem, wszedł w skład nieformalnego komitetu Kongresu odpowiedzialnego za obszar Europy Środkowowschodniej. Przez długie lata, prowadził także szeroko zakrojoną działalność podczas licznych spotkań i seminariów organizowanych pod auspicjami Kongresu Wolności Kultury.

Szczególną formą wsparcia udzielonego pisarzowi stało się finansowanie jego książek, które wydawane były przez Instytut Literacki. W ramach bardzo niewielkiej pomocy finansowej Kongresu przyznawanej dla „Kultury”, szczególne miejsce na jej liście wydawniczej zajmowały utwory Miłosza. W 1958 r. Kongres sfinansował Wybór pism, antologię Simone Weil w opracowaniu Miłosza, a w 1962 r. — z trzech pozycji, które pomógł wydać „Kulturze” w ciągu tego roku — pokrył koszty i honoraria dwóch książek samego Miłosza (Człowiek wśród skorpionów i Król Popiel). Jak wynika z archiwów Kongresu w Chicago, książki Miłosza miały zawsze zdecydowane pierwszeństwo przed innymi polskimi autorami. Wnioskujemy to z listu długoletniego szefa Kongresu i agenta CIA, Michaela Josselsona, do swego następcy, agenta Johna Hunta.

${ }^{4}$ M. A. Supruniuk prześledził udział Polaków w pracach Kongresu Wolności Kultury w swojej książce Przyjaciele wolności, poruszając epizody takie jak chociażby udział Polaków w założycielskim kongresie w Berlinie w 1950 r. (s. 25-26), i w sposób szczegółowy rozpatrzył temat uniwersytetu dla uchodźców (rozdział: Uniwersytet dla studentów zza żelaznej kurtyny. Projekt Józefa Czapskiego i Jerzego Giedroycia, s. 53-116). Szczególnie istotne, z naszej perspektywy, są badania udziału Czesława Miłosza w pracach Kongresu (fragment o drukach i thumaczeniach pism Miłosza w czasopismach i wydawnictwach związanych z Kongresem, s. 44-45), czemu poświęcił także uwagę w artykule Czesław Miłosz i Kongres. 
W ramach pomocy „Kulturze”, przewidywał sfinansowanie w 1962 jednej książki Miłosza, następnie Stempowskiego i dopiero w następnym roku Kongres mógłby pomóc Gombrowiczowi:

Mój sposób myślenia jest taki, że powinniśmy rozszerzyć naszą pomoc, aby pokryć możliwie największą ilość różnych polskich pisarzy, z wyjątkiem od tej reguły uczynionym dla Miłosza (który ma zawsze pierwszeństwo) - pisał Josselson ${ }^{5}$.

Ma rację Giedroyc pisząc, że Miłoszem Kongres bardzo się „zaopiekował” i odegrał ważną rolę w jego lansowaniu ${ }^{6}$. Nie podlega dyskusji, że Kongres Wolności Kultury był trwałym oparciem dla przyszłego noblisty w najtrudniejszych latach emigracyjnych. Jednak dla Kongresu współpraca Miłosza była nie do przecenienia. Szczególnie istotny był jego udział w seminarium w Andlau (10-15 września 1951), które poświęcone było postawie intelektualistów wobec komunizmu. Warto zauważyć, że to spotkanie było zainspirowane właśnie sytuacją Miłosza i jego pojawieniem się w orbicie Kongresu. Miłosz przedstawił tam odczyt, który był podstawą do dyskusji: „Le problème de l'intellectuel derrière le Rideau de Fer" (drugi tekst został przedstawiony przez Juliusza Margolina: „Le Diamat comme base de l'État sovietique”). Seminarium koncentrowało się wokół odpowiedzi na dwa główne pytania: jak dotrzeć do umysłu intelektualisty komunistycznego; i jak odpowiedzieć na wyzwanie, które stanowi Diamat (materializm dialektyczny), tzn. jaką akcję przeciw Diamatowi można zaproponować intelektualistom ,wolnego świata”. Spotkanie w Andlau stało się istotnym impulsem dla transformacji Kongresu od „narzędzia walki przeciw totalitaryzmowi do międzynarodowego forum debaty"7, a pozyskanie Miłosza — ważnym sukcesem ideologicznym w pierwszym roku jego działalności ${ }^{8}$.

Wartym podkreślenia jest fakt, że Miłosz jednak od początku starał się „,wymanewrować” z uprawiania lewicowej krytyki komunizmu i stania się ,ekspertem od komunizmu", jak inni polityczni uchodźcy9. Jak wspomina,

już wszystko [było] przygotowane, żebym został publicystą piszącym o sprawach komunizmu, o sprawach lewicy, polityki, w sposób jak najbardziej liberalny i anty, i co kto woli, ale w zakresie tych zagadnień ${ }^{10}$.

W swoim artykule $N i e^{11}$, znajdując się przecież w dramatycznej sytuacji życiowej, Miłosz jasno wyraził chęć pozostania niezależnym wobec polskiej emigracji politycznej i deklarował, że nie zamierzał odgrywać roli „rozczarowanego komunisty” na niczyje potrzeby polityczne. Czynił tam aluzję do rozczarowanych eks-komunistów i ich nienawiści, ,jaka często pochodzi z poczucia odstępstwa i z sekciarstwa”. Określał sam komunizm z punktu widzenia poganina, który chce go zrozumieć, jako „Nową Wiarę,

\footnotetext{
${ }^{5} \mathrm{IACF}, \mathrm{II} / 187$; f. 3, list z 29 listopada 1961.

${ }^{6}$ J. Giedroyc, Autobiografia na cztery ręce, oprac. i posł. opatrzył K. Pomian, Warszawa 1994, s. 176 („Archiwum Kultury”, t. 2).

${ }^{7}$ G. Scott-Smith, The Politics of Apolitical Culture. The Congress for Cultural Freedom, the CIA and Post-War American Hegemony, London 2002, s. 139 („,PSA Political Studies”, t. 2).

${ }^{8}$ F. Stonor Saunders, Who paid the piper? The CIA and Cultural Cold War, London 1999. W cytatach opieram się na hiszpańskim wydaniu tej książki: La CIA y la guerra fría cultural, Madrid 2001, s. 148.

${ }^{9}$ R. Gorczyńska, Podróżny świata, Kraków 2002, s. 90.

${ }^{10}$ A. Fiut, Czestawa Mitosza autoportret przekorny. Rozmowy Aleksandra Fiuta z Mitoszem. Kraków 1988, s. 36-37.

${ }^{11}$ Cz. Miłosz, Nie, Kultura 1951 nr 5(43), s. 3-13.
} 
której hołduje dzisiaj tylu ludzi zrozpaczonych, rozgoryczonych i nigdzie indziej nie znajdujących nadziei”" ${ }^{\prime 2}$. Metodycznie i konsekwentnie odrzucał Miłosz interpretacje tych, którzy nie dostrzegali rozmaitych zagadnień filozoficznych i etycznych epoki. Taki sposób stawiania sprawy na pewno nie należał do normy w czasach, które cechował raczej manicheistyczny sposób ujmowania rzeczywistości. Jednak dla Miłosza zawsze było ważne w imię czego potępiało się komunizm i nie były to racje polityczne, chociaż epoka obligowała do deklaracji w tym zakresie.

Oczywiście były tego konsekwencje i przez kolejnych dziewięć lat, Miłosz nie dostał wizy amerykańskiej. Jak wynika z dokumentów przechowywanych w Archiwum Uniwersytetu Chicagowskiego, nie pomogła tu ani jego współpraca z Kongresem ${ }^{13}$, ani interwencje sławnych intelektualistów, jak choćby francuskiego filozofa Jacques'a Maritain'a, który w liście z 4 listopada 1951 osobiście prosił Kongres Wolności Kultury o pomoc dla Miłosza. W odpowiedzi z 23 listopada 1951, Sekretarz generalny Kongresu Nicolas Nabokov, obiecywał, że Kongres zrobi w tej materii wszystko, co w jego mocy, jednak wskazywał na opozycję Polonii w Stanach ${ }^{14}$. Podjęte starania o przyznanie Miłoszowi wizy nie przyniosły rezultatu i jesienią 1953 r. Michael Josselson zdecydował się wstrzymać działania Kongresu w tej kwestii. Najwyraźniej działo się to zresztą zgodnie $\mathrm{z}$ intencją poety, który od wiosny 1953 nie starał się już o amerykańską wizę ${ }^{15}$.

Nie było tak jednak od początku. W swym liście skierowanym do Josselsona, datowanym na 5 sierpnia $1951^{16}$, Miłosz mówi, że w swoich staraniach o wizę napotyka wszędzie na „mur uniwersalnej obojętności”. Dręczony jest niepokojem o rodzinę (przebywającą w Stanach Zjednoczonych) i strachem przed represjami ze strony rządu w Warszawie. Jednak najbardziej widoczne jest załamanie psychiczne:

Zerwałem z Polską, ponieważ czułem, że nie powinienem używać mojego pióra w służbie Stalinizmu. Miałem nadzieję, że będę w stanie działać przeciwko tyrańskiej władzy. Teraz, sześć miesięcy po tym jak zerwałem, stałem się wrakiem człowieka. Tracę siłę oporu i jestem chory z oburzenia na tych ludzi, którzy uważają za swój obowiązek zniszczenie mnie — tylko dlatego, że nie uciekłem wcześniej ${ }^{17}$.

Pomimo stanu, w jakim się znajduje w pierwszych miesiącach po swojej „ucieczce", Miłosz oświadcza, że nie zamierza ugładzać (placate) wrogich mu emigrantów pisząc podlizujące się (fawning) artykuły. Mówi:

12 Tamże, s. 4 .

${ }^{13} \mathrm{~W}$ archiwum znaleźliśmy także informację, że w sierpniu 1955 r., Rockefeller Foundation odmówiła Miłoszowi grantu, co jest absolutnie niewytłumaczalne dla Nicolasa Nabokova, który w swoim liście do Miłosza z 18 sierpnia 1955 uspokaja go, że fakt ten nie ma żadnego związku $\mathrm{z}$ tym, że dla władz amerykańskich jest on persona non grata; IACF, I/5; f. 4. Bliższą informację o projekcie odnajdujemy w liście Miłosza adresowanym do Nabokova, z 23 lutego 1955. Chodziło tu o podróż do Indii, której celem byłaby praca nad książką, która miała być wynikiem obserwacji, obrazów i lektur na temat tamtej rzeczywistości. Zaznaczał w swoim projekcie Miłosz: „Nie jestem człowiekiem politycznym i nie chciałbym prowadzić krucjaty w imię żadnej sprawy, raczej wchłonić specyficzną cywilizację"; IACF, II/117; f. 10. Być może to właśnie ta deklaracja apolityczności była powodem nieprzyznania pomocy.

${ }^{14}$ IACF, II/ 222; f. 1.

${ }^{15}$ Wnioskujemy to z jego listu z kwietnia 1953 do Giedroycia; zob.: Listy 1952-1963, s. 116.

${ }^{16} \mathrm{IACF}, \mathrm{II} / 233$; f. 5.

17 „I broke with Poland because I felt I should not use my pen in the service of Stalinism. I hoped to be able to act against the tyrannical force. Now, six months after I broke, I am reduced to the state of a human wreck. I am loosing my strength of resistance and I am sick with indignation at those people who consider their duty to destroy me, only because I did not escape earlier". 
Uciekłem, aby uniknąć kłamania. Nie ma sensu uciekać, jeśli zmusza się mnie do tego żebym używał innego typu kłamstw ${ }^{18}$.

Dla Miłosza jest oczywiste, że cierpi on prześladowania z powodu swojej „postawy niezaangażowanej" (uncompromising attitude). Nawiązując wprost do ideałów głoszonych przez Kongres, dodaje:

Jestem przeciwko stalinowcom i przeciwko reakcjonistom. Jeśli taka postawa jest nie do utrzymania w obecnym świecie, to jakakolwiek wolność kultury jest niemożliwa do utrzymania $^{19}$.

Dla Miłosza było jasne od początku, że to jego niezależna postawa była źródłem jego problemów. W przyszłości należałoby jednak zbadać hipotezę, iż być może to nie restrykcyjne przepisy amerykańskie ani nagonki Polonii były najważniejszymi powodami dla dalszego „trzymania” Miłosza we Francji. Dziwne i niekonsekwentne wydaje się bowiem zachowanie Jamesa Burnhama, przyjaciela Giedroycia i Czapskiego i doradcy CIA, który w ramach „konspiracyjnych” działań wraz z ekipą „Kultury”, aby „pozyskać” emigrację polityczną Miłosza (oczywiście, rację ma M. Supruniuk wskazując na polityczne i strategiczne motywacje Giedroycia ${ }^{20}$ ), miał zagwarantować poecie szybki wyjazd do Stanów ${ }^{21}$. Później najwyraźniej jednak coś ten wyjazd zupełnie uniemożliwiło. Możliwe jest więc, że, dla strategów zimnowojennych i samego CIA, główną przyczyną wstrzymywania Miłosza w kraju, który był intelektualnym bastionem pisarzy-,,neutralistów”, była możliwość jego pragmatycznego wykorzystania na polu ideologicznej walki z komunizmem ${ }^{22}$. „Paradoks”, na który zwróciła uwagę Sarah Miller, zacytowana przez Franaszka („oto jeden z wydziałów CIA, walcząc z komunizmem, uniemożliwiał Miłoszowi przyjazd do Stanów, gdy inny w tym samym czasie - poprzez Kongres - wykorzystywał go do tejże walki" ${ }^{\prime 23}$ ), przestaje być paradoksem, gdy odwrócimy tę frazę: oto jeden z wydziałów CIA, walcząc z komunizmem, uniemożliwiał Miłoszowi przyjazd do Stanów, tym samym umożliwiając by inny w tym samym czasie — poprzez Kongres — wykorzystywał go do tejże walki.

\section{Zniewolony umyst dla Miłosza i dla innych}

Studia na temat roli, położenia, misji i winy intelektualistów wobec totalitaryzmu należały do najbardziej rozpowszechnionych w latach 50. i wiele $\mathrm{z}$ nich zostało sfinansowanych przez Amerykanów. Powstawały one, z jednej strony, jako odpowiedź na swego rodzaju ogólny kryzys moralny, na który cierpiała inteligencja europejska w wyniku swojej postawy wobec nazizmu (problem kolaboracji był szczególnie istotny

18 „I escaped in order to avoid lying. There is no reason to escape if one is to be compelled to use a different type of lies".

19 „I am against stalinists and against reactionaries. If such an attitude is untenable in the present world, than any freedom of culture is untenable".

${ }^{20}$ M. A. Supruniuk, Przyjaciele wolności, s. 141-142, 153-168. Supruniuk proponuje nawet aby przyjąć rok 1951 jako kres „względnej jedności emigracji” (s. 164).

${ }^{21}$ A. Franaszek. Mitosz. Biografia, Kraków 2011, s. 475. Proces ten, który Giedroyc nazywał „robótką”, Franaszek opisuje ze szczegółami (s. 480-481).

${ }^{22}$ Warto w tym kontekście przypomnieć sobie słowa Bondy'ego o ogromnym znaczeniu Miłosza dla Kongresu i stopniowego „przyciągania” dzięki niemu lewicy francuskiej; F. Bondy, Intelektualna Europa, wywiad I. Chruślińskiej, Przegląd Polityczny 1997 nr 33/34.

${ }^{23}$ A. Franaszek, Mitosz, s. 483. 
dla intelektualistów francuskich). Innym ważnym impulsem do ich powstawania była specyficzna koniunktura polityczna, która, na fali rozliczeń z nazizmem, domagała się analizy postawy inteligencji wobec stalinizmu oraz stworzenia takiego klimatu intelektualnego i ideologicznego, który umożliwiłby przezwyciężenie komunistycznych sympatii wśród intelektualistów zachodnich. Podobnie jak w przypadku innych tego typu dzieł, Kongres aktywnie przyczynił się do promocji Zniewolonego umystu na całym świecie, thumacząc go na wiele języków ${ }^{24}$. Ma jednak rację Kornat kiedy mówi, że książka ta nie była „produktem zimnej wojny” 25 , jednak nie tyle ze względu na samą tematykę którą poruszała, lecz na sposób w jaki to robiła.

Powstały w ciągu $1951 \mathrm{r}^{26}$ Zniewolony umyst był próbą głębokiego spojrzenia na sytuację inteligencji w kraju, przez pryzmat osobistych doświadczeń. Miłosz przyznaje, że pisał tę książkę w poczuciu „zobowiązania moralnego" ${ }^{27}$ i proces jej powstawania określa jako próbę własnego wydostania się z „korkociągu” ideologii ${ }^{28}$. Wskazuje na swój tomik poezji Traktat moralny (1947) jako szkic do Zniewolonego umystu, a powieść Zdobycie władzy (1953) jako pochodną tego ostatniego, jednak zarazem etap pisania Zdobycia władzy i Zniewolonego umystu nazywa okresem kariery „literata żyjącego z honorariów"29. Pomimo więc faktu, że Zniewolony umyst wyrasta w pewnym sensie z problematyki poruszonej już w Traktacie moralnym, Miłosz wielokrotnie podkreślał, że tematyka podjęta w tej książce to nie jego specjalność. Swoiste historyczno-ideologiczne „upupienie”, jakie zdarzyło się Miłoszowi po napisaniu Zniewolonego umystu sprawiło, że porównywał swe losy do losów Pasternaka, który dostał Nagrodę Nobla za Doktora Żywago, podczas gdy to poezja „była jego życiem””30. W Roku myśliwego, podsumowując ten etap swojej twórczości wskazuje na trzy skutki Zniewolonego umystu: zaprzepaszczenie wizy do Ameryki na okres dziewięciu lat, „piętno zdrajcy” wśród lewicowej inteligencji francuskiej i zaliczenie go w poczet pisarzy politycznych ${ }^{31}$.

Skutków napisania Zniewolonego umystu było jednak znacznie więcej. Był to pierwszy głos, który nie potępiał w sposób banalny inteligencji krajów komunistycznych, tak jak to czyniła większość środowisk antykomunistycznych na Zachodzie. Wiedzą na temat sytuacji intelektualistów na Wschodzie, Miłosz wyprzedzał znacznie

${ }^{24} \mathrm{~W}$ archiwum Biblioteki Regenstein zachował się oryginalny szkic Zniewolonego umystu; IACF, II/233; f. 5. M. A. Supruniuk wskazuje, iż to właśnie Kongres przyczynił się w sposób definitywny do promocji tego zbioru esejów na świecie; Czestaw Mitosz i Kongres, s. 98.

${ }^{25}$ M. Kornat, Między literatura a polityka. Korespondencja Jerzego Giedroyca z Czestawem Miłoszem (1952-2000), [w:] J. Giedroyc, Cz. Miłosz, Listy 1952-1963, s. 22.

${ }^{26}$ O. Glondys, ,Zniewolony umyst” Czestawa Miłosza, s. 221. Cytowany artykuł, m.in., analizował proces powstawania Zniewolonego umystu, porównując gotową książkę i szkice do jej rozdziałów opublikowane wcześniej po francusku w „Preuves”. Warto zauważyć, że tekstami, które tematycznie i chronologicznie uzupełniały Zniewolony umyst, były szkice Wielkie pokuszenie i Poezja i dialektyka. Trafną tezę, że Wielkie pokuszenie było swego rodzaju szkicem do Zniewolonego umystu wysunął Supruniuk; zob.: „Wielkie pokuszenie”, albo zapomniany. W 2002 r. nakładem Archiwum Emigracji ukazało się pierwsze w Polsce wydanie tego tekstu (razem ze szkicem Bieliński i jednorożec). Szkic o poezji i dialektyce ukazał się w „Kulturze” (1951 nr 6, s. 32-39), zaś w Polsce tylko raz, w 1985 r., nakładem podziemnego wydawnictwa CDN.

${ }^{27}$ A. Fiut, Czestawa Mitosza autoportret, s. 119.

${ }^{28}$ Cz. Miłosz, Rok myśliwego, Paryż 1990, s. 149.

${ }^{29}$ R. Gorczyńska, Podróżny świata, s. 88, 113.

${ }^{30}$ Tamże, s. 92.

${ }^{31}$ Cz. Miłosz, Rok myśliwego, s. 149. 
swoich zachodnich kolegów i jak nikt inny umiał wczuć się głęboko w problemy pisarzy i intelektualistów za żelazną kurtyną. Sytuację duchową Miłosza w tamtych latach można by porównać do rozdarcia pomiędzy polskim środowiskiem literackim, którego czuł się jeszcze częścią ${ }^{32}$, i już postawą emigracyjną, zewnętrzną. Starania Miłosza, aby pisząc Zniewolony umyst, zachować część własnego decorum moralnego wobec pisarzy w kraju są ewidentne. Świadomie usytuował swą książkę ponad wszelkim manicheizmem, operując niuansem, delikatnością i potrzebą zrozumienia psychologicznych i filozoficznych uwarunkowań intelektualistów za żelazną kurtyną, których przypadki rozważał pojedynczo. W tenże sposób stworzył książkę ponadczasową, której głębokie przesłanie trafiało do międzynarodowego odbiorcy o różnych zapatrywaniach.

Potwierdza to lektura tekstów poświęconych Zniewolonemu umystowi, napisanych przez najwybitniejsze i najbardziej prawe umysły tamtej epoki ${ }^{33}$. Karl Jaspers, Benedetto Croce, Albert Camus czy Dwight McDonald, nie tylko nie podzielali sceptycyzmu Miłosza wobec Zniewolonego umystu, lecz uważali jego głos za niepowtarzalny i poruszający najgłębsze pokłady myśli i uczucia. Karl Jaspers pisał:

Miłosz nie pisze jak nawrócony komunista, nie spotyka się u niego śladu tego agresywnego fanatyzmu wolności, który w gestach, tonie i zachowaniu działa jak odwrócony totalizm. Nie pisze też jak opozycyjny emigrant, który w gruncie rzeczy myśli o przewrocie i powrocie. Przemawia jako człowiek wstrząśnięty, którego troska o sprawiedliwość, o nieskrzywioną prawdę zmusza — poprzez analizę wydarzeń pod terrorem do odsłaniania samego siebie ${ }^{34}$.

Także Albert Einstein, który jeszcze w 1949 r. odradzał pójście Miłoszowi na emigrację, napisał do niego pełen podziwu list na temat Zniewolonego umystu ${ }^{35}$. Wyrażał tam opinię, że książka jest bardzo ważnym wkładem dla lepszego zrozumienia przez intelektualistów zachodnich sytuacji za żelazną kurtyną. Pozwalała właściwie ocenić wpływ dramatycznych przeżyć, w ciągu ostatnich piętnastu lat, na mentalność i charakter tamtejszej inteligencji. Pisał dalej Einstein:

Jest takie powiedzenie w Talmudzie, że nie powinien być Sędzią ten, kto nie znalazł się w podobnej sytuacji jak oskarżony. Uważam, że nikt w krajach Zachodu nie może spełnić tego warunku. Więc nie powinien próbować osądzać, co najwyżej starać się zrozumieć. Nie spotkałem się z publikacją, która dawałaby głębszy ogląd z psychologicznego punktu widzenia, niż twoja książka. Udało ci się także odeprzeć pokusę, aby wkraść się w łaski zachodniego czytelnika idealizując warunki w krajach Zachodu. Twoja książka będzie wkładem do takiego rodzaju zrozumienia, które jest pierwszym warunkiem dla osiągnięcia pokoju na całym świecie ${ }^{36}$.

${ }^{32}$ W rozmowie z Anną Bikont i Joanną Szczęsną, Miłosz mówił, że nawet będąc na emigracji dalej czuł się niejako częścią krajowego środowiska literackiego: „To dlatego między innymi że podzielałem niektóre lojalności tego środowiska, zerwanie było dla mnie takie trudne. Łączył nas pewnego rodzaju kodeks, prawda, pokrętny i dziwny... Było we mnie mnóstwo ambiwalencji”; zob.: A. Bikont, J. Szczęsna, Lawina i kamienie. Pisarze wobec komunizmu, Warszawa 2006, s. 191.

$33 \mathrm{O}$ reakcjach zachodnich intelektualistów na Zniewolony umyst, piszą także Supruniuk (Przyjaciele wolności, s. 149-150) i Franaszek (Miłosz, s. 490).

${ }^{34}$ K. Jaspers, O książce Miłosza, Kultura 1953 nr 6(68), s. 119.

${ }^{35}$ List odnaleziony w Archiwum Kongresu Wolności Kultury w Chicago (IACF, VII/9; f. 9). Nie posiada on daty, jednak należy ją przyjąć na lipiec 1953, gdyż prawdopodobnie chodzi tu o ten sam list, który wspomniany jest przez Franaszka (Miłosz, s. 490 i przyp. 107 na s. 847).

36 "There is a saying in the Talmud that nobody should be Judge who has not been in a similar situation as the defendant. I believe that nobody in the Western countries can fulfill this con- 
Pomimo tak pozytywnego odbioru przez ludzi jak Jaspers czy Einstein, jasne było jednak to, że Miłosz nie chciał więcej wracać do tematyki poruszonej w Zniewolonym umyśle. I to pomimo tego, że wielu zachęcało go do kontynuowania podobnych rozważań.

\section{Fiasko Zniewolonego umystu 2}

Propozycję powrotu do tematu Miłosz dostał zarówno od Kongresu Wolności Kultury, jak i od samego Jerzego Giedroycia. Z archiwum Uniwersytetu Chicagowskiego dowiadujemy się, że szef „Der Monat” i wpływowy członek Kongresu Melvin Lasky pisze w tej sprawie do Miłosza 6 listopada 1957 r. ${ }^{37}$ W liście wspomina o nowym planie wydawniczym Kongresu, który zakładałby edycję książki, która „,wzięłaby pod lupę cały problem tego, co zostało określone jako «Pisarze Wolności» [The Freedom Writers]". Prosi Miłosza o zgodę na napisanie polskiego rozdziału, eseju składającego się z około trzydziestu stron, który „byłby analityczny, nawet teoretyczny, ale zarazem bliski rzeczywistości”. I dalej wyszczególnia pożądany rys i tematykę tego eseju:

Informowałby o herezjach i o ideologicznym proteście, i wskazywałby na ich znaczenie dla problemu ,totalitaryzmu”. Tak jak wskazuję w planie, byłaby to dla ciebie kontynuacja dyskusji na temat problemu Zniewolonego umystu. Myślę, że zgodzisz się ze mną, że biorąc pod uwagę dyskusję, często tylko jednostronnie krytyczną, którą wzbudziły niektóre $\mathrm{z}$ twoich argumentów, byłoby dalece wskazane (a dla mnie bardzo podniecające) żebyś powrócił do niej z dodatkowymi refleksjami i być może ,ponownymi przemyśleniami" [reconsiderations].

Lasky wprost sugeruje, że wobec burzy, która rozpętała się w niektórych środowiskach w związku ze Zniewolonym umystem, byłoby „dalece wskazane” żeby Miłosz powrócił do tego tematu i nawet zmienił nieco oryginalną wymowę książki. Załącza własny „kuszący plan” tego, „co powinno lub mogłoby być zrobione” i wskazuje, iż pragnie rozmawiać z Miłoszem na jego podstawie. Choć plan ten się nie zachował, już w swoim liście szkicuje ową „kuszącą tezę”, która jest jego częścią. Lasky sugeruje więc konieczność wyjścia od tematu „końca ideologii” i krytyki w jego kontekście klasy intelektualnej i pisarzy, żądając nowego krytycyzmu oraz ,renesansu intelektualnego" w świecie zachodniej inteligencji, oraz atakując uprzywilejowane i zniewolone środowiska intelektualne w świecie komunistycznym.

Obaw poety związanych z tym projektem możemy się domyślać po lekturze kolejnego listu, z 15 listopada, w którym Lasky dziękuje za wspólny długi wieczór spędzony z Miłoszem w Paryżu:

Mam nadzieję, że nasza rozmowa wywarła na tobie wrażenie, że jak najbardziej pragnę abyś napisał, co myślisz (ze wszelkimi związanymi z tym wątpliwościami, wahaniami, problemami, komplikacjami psychologicznymi). W żadnym wypadku nie chcemy

dition. So he should not try to judge, but all the more should try to understand. I have not seen any publication which gives a deeper insight from the psychological standpoint than your book. You also have effectively resisted the temptation to curry favour with the Western reader by idealizing the conditions in the Western countries. Your book will be a contribution to that kind of understanding which is the first condition for the attainment of world wide peace". Miłosz tak mówi o Einsteinie: „Nikt chyba, kto znał Einsteina, nie mógł nie uwielbiać go jako człowieka. Uroczy absolutnie. Czarujący” i wspomina swój ,wielki kult jako dla człowieka, serdeczny bardzo"; R. Gorczyńska, Podróżny świata, s. 310.

${ }^{37}$ IACF, I/11; f. 5. 
przypasować twojego myślenia do jakiejś formy, ani wcześniej wymyślonej tezy [,fit your thinking into some mould or preconceived thesis"].

Prosi Miłosza, aby po ponownym przemyśleniu, zgodził się na napisanie tego eseju, argumentując, iż temat inteligencji w Europie Wschodniej jest, ,prawdopodobnie najpilniejszym tematem naszego czasu” i, że publiczność Zachodu czeka na takie studium właśnie $\mathrm{z}$ jego strony.

Kilka lat później, w liście z 15 stycznia 1963 (Listy, s. 689), także Giedroyc wychodzi do Miłosza z podobną propozycją i nalega, żeby:

[...] opracować esej (który byłby w pewnym sensie skorygowaną i skondensowaną wersją Zniewolonego umystu), w którym by Pan zanalizował, co myśleli i wiedzieli polscy intelektualiści bezpośrednio po zakończeniu wojny o Stalinie, jak wyglądał, jak zaciążył czy przełamywał się wśród nich mit Stalina [...]. Po dyskusji z Watem jesteśmy z nim całkowicie zgodni, że tylko Pan może coś takiego napisać i że nawet Pan to musi zrobić. Niech Pan nie odmawia. To naprawdę jest bardzo ważne i potrzebne.

Miłosz odmawia zarówno Giedroyciowi jak i Kongresowi, i w tym drugim przypadku, na pewno jednym z powodów tej decyzji była obawa pisarza, że Kongres zapragnie jednak ,przystosować” jego myślenie do wcześniej istniejącej formy lub tezy, jak to wyraził Lasky. To właśnie ten specyficzny klimat zimnowojenny i oczekiwania dyspozycyjności intelektualnej spowodowały, że Miłosz radykalnie odciął się od kontynuowania tematyki poruszonej w Zniewolonym umyśle.

\section{CZESŁAW MIŁOSZ WPLĄTANY W ZIMNĄ WOJNE KULTURALNĄ}

Miłosz napisał w Abecadle, że mógłby całą książkę napisać o Kongresie Wolności Kultury, ale że mu się nie chce. Wypowiadał się pozytywnie na temat osób związanych z Kongresem (Sidney Hook, Arthur Koestler), a nierzadko i wyrażał wobec nich podziw (Kot Jeleński, Nicola Chiaromonte, Ignazio Silone, Dwight McDonald) ${ }^{38}$. Jak wspomina Mary McCarthy, Miłosz czuł się komfortowo w środowisku lewicy niekomunistyczej (non-comunist left), która stanowiła jedno ze stronnictw ideologicznych tej organizacji $^{39}$. W Abecadle pisze, że Kongres był uzasadniony i potrzebny, bowiem jako jedyny stawiał opór komunistycznej propagandzie na Zachodzie. W 1959 r. bronił nawet jego dobrego imienia w kraju, prostując błędne rewelacje tygodnika „Polityka”, jakoby Kongres był filią Free Europe (a „Kultura” przybudówką obu organizacji) ${ }^{40}$.

Jedyną bezpośrednią krytykę znajdujemy w Abecadle, kiedy to wspomina o ostentacyjnym bogactwie jego szefów. Na sceptyczny stosunek Miłosza wobec Kongresu wskazuje także podkreślanie jego „doraźnych tylko” kontaktów z tą instytucją oraz problemy ze zdobyciem wizy amerykańskiej („,Kongres nie był za to odpowiedzialny, ale zawsze" ${ }^{41}$ ). W swoim wywiadzie z Wojciechem Dudą dla „Przeglądu Politycznego" mówi też Miłosz, że „,chyba słusznie”, że Giedroyc nie zdecydował się na zamienienie „Kultury” w pismo kongresowe, ponieważ spowodowałoby to utratę swobody działa-

\footnotetext{
${ }^{38}$ Cz. Miłosz, Abecadto, s. 99-101.

${ }^{39}$ F. Stonor Saunders, Who paid the piper?, s. 148.

${ }^{40}$ Cz. Miłosz, List do polskich komunistów, Kultura 1959 nr 11(145), s. 97-100.

${ }^{41}$ Tenże, Abecadto, s. 101. Oczywiście, kontakty te nie były bynajmniej „doraźne”, jak wynika z badań Supruniuka (Przyjaciele wolności, s. 144) i Glondys (,Zniewolony umyst” Czesta-
} wa Miłosza). 
nia (chociaż zarazem automatycznie usunęłoby wszelkie problemy finansowe) ${ }^{42}$. Jednak pełną prawdę o odczuciach i obawach poety w związku ze swoją współpracą z Kongresem możemy wywnioskować z jego korespondencji.

\section{Problemy z thumaczeniem Zniewolonego umystu}

W dobie kulturalnej zimnej wojny, klasycznym sposobem manipulacji tekstów było poddawanie ich tłumaczeniom. O problemach z tłumaczem eseju o Ketmanie na francuski, który to ,pozwolił sobie na zupełnie dowolne i nie w moim stylu zmiany” i ,awanturze z «Preuves»” wspomina Miłosz w liście do Giedroyca z lipca 1952 (Listy, s. 87). Tłumaczem, który sygnował przekład Zniewolonego umystu, jak również artykułów w „Preuves”, był francuski anarchista André Prudhommeaux. Ponieważ nie znał on języka polskiego, Miłosz w ciągu 1952 r. sam przedyktował mu, zdanie po zdaniu, tłumaczenie książki, ograniczając rolę samego Prudhommeaux do korekty stylistycznej i do firmowania. Na czym więc polegały problemy Miłosza z Prudhommeaux, o których nie wspomina w żadnej ze swych książek?

W Bibliotece Regenstein natknęliśmy się na wymianę korespondencji między Miłoszem i François Bondy'm z lipca $1952^{43}$. Listy te rzucają nowe światło na kwestię thumaczenia Zniewolonego umystu. Z korespondencji wynika, że Miłosz był tak bardzo niezadowolony $z$ thumaczenia eseju o Ketmanie przez Prudhommeaux, że zlecił zupełnie nowe thumaczenie Jeanne Hersch. Obie wersje przeczytał i porównał François Bondy, redaktor naczelny „Preuves”. List Bondy'ego do Miłosza jest bardzo „gwałtowny” (tak go kwalifikuje Miłosz), pełen wyrzutów za to, że dołożył redakcji „Preuves” dodatkowej i bezsensownej pracy i że popełnił „nieuzasadniony afront” wobec samego Prudhommeaux (dzięki którego thumaczeniom - w opinii Bondy’ego — Miłosz jest w końcu znany od roku we Francji i który dostarczył Miłoszowi „dość dowodów przyjaźni i estymy”). Bondy twierdzi, iż różnice między oboma tłumaczeniami, Hersch i Prudhommeaux, są „,minimalne", że nie zmieniają prawie w żadnym miejscu sensu tekstu, którego fundamentalny wydźwięk pozostaje ten sam i podkreśla, że tłumaczenie Hersch (do którego ma zastrzeżenia) jest po prostu ,parafrazą istniejącego tłumaczenia”.

Reakcja Miłosza jest jednoznaczna. W swoim napisanym odręcznie liście, Miłosz odpowiada Bondy'emu, że to właśnie thumaczenie Hersch jest zgodne z jego tekstem „,słowo po słowie” i że, gdyby nie jej pomoc, nie dałby w ogóle swojej zgody na publikację eseju. Oto jak tłumaczy swoje stanowisko:

Fakt jest taki : Prudhommeaux dodał dużo zdań wyjaśniających, które mi się nie podobają i wiele słów, prawie $\mathrm{w}$ k a ż d y m $\mathrm{z}$ d a n i u mojego tekstu, które też mi się nie podobają. Jestem absolutnie przeciwny oczernianiu, tak typowemu zarówno dla dziennikarzy komunistycznych, jak i dla zawodowych antykomunistów. Dla mnie, jest to kwestia zasady - $\mathrm{s}$ t y $1 \mathrm{u}^{44}$.

Złe tłumaczenie Prudhommeaux postawiło Miłosza przed koniecznością dokonania wyboru pomiędzy popełnieniem „,afrontu” albo akceptacją stylu, który jest mu „obcy”. Zauważa ironicznie:

${ }^{42}$ Cz. Miłosz, Liberalna Konspiracja, wywiad W. Dudy, Przegląd Polityczny 1998 nr 36.

${ }^{43}$ IACF, VII/9, f. 9, list F. Bondy'ego z 21 lipca i odpowiedź Miłosza z 26 lipca.

44 „Le fait est: Prudhommeaux a ajouté maintes phrases- explicatives- que je n'aime pas et maints mots, presque dans $\mathrm{chaque} \mathrm{phrase}$ de mon texte- que je n'aime pas non plus. Je suis contre de tou [sic!] de dénigrement si typique aux journalistes communistes et aux anticommunistes professionnels. Pour moi, c'est la question du principe - d u s t y l e". 
Teraz staram się zrozumieć powody, które podyktowały mu owe „wyjaśniające lania wody", jak on sam to określił. Ni e mogę z n i eś ć ironii, która idzie zbyt daleko, która przestaje być ironią i zamienia się w zbyt łatwe oczernianie przeciwnika, zbyt łatwe, ponieważ za pomocą określeń, a nie za pomocą treści ${ }^{45}$.

W swoim liście do Bondy’ego Miłosz wyraża nadzieję, że ten niemożliwy do zaakceptowania przekład Ketmana będzie wyjątkiem, chociaż wskazuje zarazem na obecność délayages Prudhommeaux także w innych planowanych rozdziałach Zniewolonego umystu (L'Occident i Les Ennoncés). Nie zgadza się z Bondy'm co do tego, że różnice między tekstami są nieznaczne i przestrzega go przed stosowaniem retoryki antykomunistycznej:

Pan, jako redaktor naczelny „Preuves”, musi sobie zdawać sprawę z niebezpieczeństwa, które grozi czasopismom tego typu. To śliski teren, owo podbijanie tonu ironicznego i złośliwego wobec przeciwników. Powinien Pan zrozumieć, że jeśli chce się trafić do publiczności, która ma wątpliwości, należy nałożyć współpracownikom ścisłą dyscyplinę i nie ustępować pokusom „bon motów”, określeń pejoratywnych (albo „wyjaśniających"), ponieważ to nie jest sposób, w jaki się mówi do ludzi, lecz jedynie sposób, w jaki się ich odrzuca ${ }^{46}$.

Niezgoda Miłosza na siermiężną retorykę antykomunistyczną wynikała z dwóch przesłanek. Pierwszą z nich był szacunek do problemów i debat, które podnoszone były w tamtym okresie: jeżeli chciano brać w nich udział i przyciągnąć wahających się, należało mówić racjonalnie, argumentować, szukać ambitnych rozwiązań dla niepokojów intelektualnych i etycznych epoki. To właśnie miał na myśli pisząc do Bondy’ego, że nie może znieść „złośliwej ironii”, ponieważ oznaczała ona „zbyt łatwe oczernienie” przeciwnika, za pomocą retoryki, a nie treści. Drugim powodem była niezgoda Miłosza, jako poety i stylisty, na upraszczający i generalizujący język stosowany w tego typu artykułach: „To dla mnie kwestia zasady — s t y 1 u”, podkreślał.

\section{Z kim się utożsamia twórca, czyli o Zdobyciu władzy}

W tamtych latach, niewielu potrafiło docenić głębię i subtelność utworów Miłosza, i prawie wszyscy krytycy i komentatorzy (zarówno zwolennicy, jak i krytycy komunizmu) żądali od pisarza gotowych i prostych odpowiedzi na ówczesne potrzeby polityczne.

W Roku myśliwego Miłosz wspomina, że do napisania Zdobycia władzy zmusiła go Jeanne Hersch, i że napisał ją, aby zrobić jej przyjemność i też dla eksperymentu ${ }^{47}$.

45 „Maintenant je tâche de comprendre les motifs qui lui ont dictés les «délayages explicatifs» comme il m'a écrit lui-même. J e ne peux pas supporter l'ironie qui va trop loin, qui cesse d'être ironie et devient un dénigrement trop facile de l'adversaire, trop facile, car a travers les termes et non a travers le contenu".

46 „Vous, comme rédacteur des «Preuves» devez vous rendre compte du danger qui menace des périodiques de ce genre. C'est une pente savonneuse, la surenchère du ton ironique et malicieux envers les adversaires. Vous devez comprendre que si on veut atteindre le public hésitant on doit imposer aux collaborateurs une discipline stricte et ne pas céder aux tentatives de bons mots, termes péjoratifs (ou «explicatifs») car ce n'est pas le moyen de parler, seulement le moyen de repousser les gens".

${ }^{47}$ Cz. Miłosz, Rok myśliwego, s. 246. 
O jednej z pierwszych recenzji tej powieści, autorstwa Manesa Sperbera ${ }^{48}$, pisze w swym liście do Giedroycia (luty 1954) w sposób następujący:

bardzo mi się nie podoba, ponieważ nie jest to analiza wad literackich utworu, ale pretensja dokładnie taka, jak w Warszawie, tylko na odwrót. [Sperber] Chciałby „pozytywnego bohatera" antykomunistycznego (Listy, s. 167).

W zbiorach Biblioteki Regenstein odnaleźliśmy list, który pozwala zrozumieć, dlaczego Miłoszowi nie podobała się ta recenzja.

W tym liście do Sperbera, z początku 1954 r. (brak dokładnej daty) ${ }^{49}$, Miłosz zastrzega, że broni swojej powieści nie pod względem literackim, lecz ideologicznym. Polemizuje z sugestią recenzenta jakoby miał się solidaryzować z postacią Kwinto, uważając, że autor nie ma potrzeby identyfikowania się z bohaterami swych utworów. Wskazuje, że „moralizująca pasja” (passion de moraliste) Sperbera zanosi go za daleko w momencie, gdy krytykuje Miłosza na podstawie jego rzekomego utożsamiania się $\mathrm{z}$ postacią, która się Sperberowi nie podoba z moralnego punktu widzenia. Porównuje jego moralizatorskie myślenie i nagabywania, żeby Miłosz się „zdefiniował”, do atmosfery aktualnych, „dialektycznych” dyskusji prowadzonych w Związku Pisarzy Polskich w Warszawie oraz do powojennych reakcji marksistów na Ocalenie (1945) Miłosza. (Tomik ten, zakończony słowami „Prawda” i „Sprawiedliwość”, został skrytykowany przez marksistowską krytykę, która kazała te idee zdefiniować, aby zakwalifikować ideologicznie młodego pisarza i pokazać jego bezbronność w poszukiwaniu owych idei bez marksizmu.) Odnosząc się do kwestii wiary i etyki, w dalszej części swego listu, Miłosz pisze:

Pan wymaga ode mnie żebym zdefiniował wiarę. Kto dziś może Pana usatysfakcjonować bez popadnięcia w głupstwa? Mam wrażenie, że brak antykomunistycznego bohatera $\mathrm{w}$ literaturze związany jest właśnie z tym wymogiem: żeby zdefiniować pewne słowa. Gdy ktoś poddaje się myśleniu marksistowskich krytyków: j a k a prawda? j a $\mathrm{k}$ a sprawiedliwość? naraz czuje się zbyt subiektywny, pusty, nieokreślony, i już nie jest w stanie dłużej walczyć. Moja prezentacja [chodzi tu o prezentację książki], tak jak Pan ją rozumie, będzie niemożliwa do podtrzymania. Dlatego, że Pan zbywa milczeniem metafizyczny wymiar książki [...]. Naprawdę, czy Pan nie widzi mojej intencji, aby podnieść człowieka jako metafizycznej egzystencji — w warunkach, gdzie podnieść jedno włókno jest jak podnieść 1000 kilowy ciężar? Dlaczego włókno się nie liczy? Dlatego, że dla kogoś z zewnątrz jest niczym więcej jak włóknem? Wymaga się spektakularnych działań od tych, którzy są tam, ale nie rozumie się, że powiedzenie na uniwersytecie co się myśli, albo odmówienie wstąpienia do partii to dla komunistów są właśnie d z i a ła n i a. Pan mówi o, „zgniliźnie” [Sperber określa tak wszystkie postaci powieści]. Ja nie jestem moralistą. [...] Mówię Panu, że ja nie mam talentu moralizatorskiego i, prawdę mówiąc, to czuję się solidarny ze wszystkimi postaciami ${ }^{50}$.

${ }^{48}$ M. Sperber, La prise du pouvoir, Kultura nr 3(77), s. 129-134. Recenzja zatytułowana Le romancier et la chronique révolutionnaire. A propos de „La prise de pouvoir” de Czeslaw Milosz ukazała się także w „Preuves” (1954 nr 37, s. 88-91).

${ }^{49} \mathrm{IACF}, \mathrm{VII} / 9$; f. 9.

50 „Vous exigez que je définisse la foi. Qui aujourd'hui peut vous satisfaire sans retomber dans les platitudes? J'ai l'impression que le manque du héros anti-communiste dans la littérature est lié avec cette exigence: qu'on définisse certains mots. Quand on est sensible aux questions des critiques marxistes: qu e 11 e vérité? q u e 11 e justice? on se sent trop subjectif, vide, vague, et on ne peut plus lutter. Ma présentation, comme vous la concevez, serait intenable. Car vous passez sous silence la dimension métaphysique du livre [...]. Est-ce que vous ne voyez, vraiment, mon intention de rehausser l'être humain en tant qu'un être métaphysique — dans les 
Miłosz czuł się rozczarowany kompletnym niezrozumieniem książki przez Sperbera. Jednak uproszczenia interpretacyjne nie były domeną wyłącznie zagranicznych krytyków i recenzentów. Także w polskiej krytyce znajdujemy podobne poszukiwanie dosadnych i prostych interpretacji skomplikowanej materii pism Miłosza, i w tym przypadku, Zdobycia władzy. O jednej z recenzji tej powieści, wspomina Miłosz w rozmowie z Gorczyńską:

Zarzuca mi dążenie do utrzymania równowagi wszystkich postaw, które się wzajemnie znoszą. To znaczy, że tam nie ma żadnego dobrego rozwiązania, że wszystkie racje są złe. Recenzent widzi w tym coś niemoralnego ${ }^{51}$.

Skonfundowany Miłosz prosi Gorczyńską o jej zdanie na temat wydźwięku książki oraz pyta, czy można w niej znaleźć obronę jakichś konkretnych wartości. Najwyraźniej samo wspomnienie tych problemów go nie zadowala bowiem konstatuje: ,ja nie lubię tej książki”. Zaprzecza kategorycznie jakoby Zdobycie władzy było powieścią z kluczem i sugeruje wręcz, że powieść ta była znacznym uproszczeniem wobec prawdy o tamtym czasie:

Poza tym, biorąc pod uwagę moją wiedzę o rzeczywistości tamtego okresu, to książka ta tak się ma do tej rzeczywistości, jak równanie matematyczne do świata pełnego kolorów, barw i indywidualnych odcieni. To jest wykoncypowane. To jest robienie jakiegoś ekstraktu postaw ludzkich. Natomiast nie ma wszystkiego tego, co było decydujące ${ }^{52}$.

Materia literacka u Miłosza, jako próba wiernego odzwierciedlenia pewnej rzeczywistości, jest zagmatwana, ponieważ właśnie taki jest jej pierwowzór. Autor czuje się solidarny i pochyla się nad całą metafizyczną materią rzeczywistości, którą przedstawia. Nie należy jej upraszczać na siłę.

\section{Nigdy nie mów nigdy, czyli o tłumaczeniu Opium des Intellectuels}

Dystansowanie się Miłosza wobec propozycji Kongresu miało jednak swoją granicę. $\mathrm{Z}$ potrzeb czysto materialnych pisarz przetłumaczył na język polski Opium des Intellectuels Raymonda Arona, i książkę tę wydała „Kultura” przy finansowej pomocy Kongresu Wolności Kultury. Na swoje życzenie, Miłosz nie firmował tego przekładu, ze względu na absolutny brak zgody na linię ideologiczną reprezentowaną w niej przez Arona. Jeszcze kilka miesięcy wcześniej, we wrześniu 1955, przyszły tłumacz zażegnywał się:

Natomiast Arona Opium des Intellectuels $\mathrm{n}$ i g d y [sic!] bym nie tłumaczył. Jest to zła książka. Mija się z zagadnieniem, żadnego komunisty nie przekona i może służyć za przykład jak nie należy pisać o komunizmie (Listy, s. 233-234).

circonstances ou soulever un brin est comme soulever un fardeau de 1000 kilos? Pourquoi le brin ne compte pas? Parce que pour quelqu'un de l'extérieur ce n'est q'un brin? On demande des actes spectaculaires de ceux là-bas, mais on ne comprend pas que dire a l'université ce qu'on pense, ou renoncer a entrer le parti socialiste rallié aux communistes sont des a c te s. Vous dites «pourriture». Je ne suis pas moraliste. [...] Je vous dis que je n'ai pas de talent de moraliste et, qu'à vrai dire, je me sens solidaire avec tous les personnages".

${ }^{51}$ R. Gorczyńska, Podróżny świata, s. 114. Chodzi tutaj prawdopodobnie o recenzję: [P. Kłoczowski] PMK, Czytanie Miłosza: „Zdobycie władzy”, Res Publica 1979 nr 2, s. 112-116.

52 Tamże, s. 115. 
W marcu 1956, gdy znajduje się na 310 stronie thumaczenia, pisze do Giedroycia długi list, (Listy, s. 255-256) w którym stwierdza: „Zupełną nicość książki Arona poznaje się dopiero w tłumaczeniu”. Chodzi tutaj nie tylko „o to, że jest ona bardzo słaba”, lecz o sposób „ubijania” poważnych tematów, zasługujących na rozważenie, i które Aron sprowadza „do niebywałej płaskości”. Miłosz porównuje tekst Arona do „ciepłych klusek” i „bredzenia babci nad robótką”, wskazuje na pustkę treściową, nieautentyczność tonu, „słabość myśli”, „nieznośne poczucie banału od początku do końca” i ,zdumiewający brak poczucia formy”. Książka może czytelnika, szczególnie tego zza żelaznej kurtyny, skutecznie zniechęcić do Zachodu i spowodować rozczarowanie, które jest „,moralną trucizną”. Wreszcie, jako „książka ideologiczna” („Czego autor chce, nie wiadomo. To tylko wiadomo, że pochwala Stany Zjednoczone”) i zła, szkodzi „Kulturze”.

Miłosz żałuje, że podjął się tej pracy i jest „,poważnie zmartwiony”, opisując swoją sytuację następująco:

Niestety często zdarza mi się wpadać w błoto i potem tego żałować. To jest kwestia moralnej odpowiedzialności przyłożenia ręki do czegoś, co jest szkodliwe. Nie miałbym skrupułów, gdyby chodziło o pornograficzny utwór, ale tu sprawa przedstawia się poważniej.

Za wszelką cenę stara się przekonać Giedroyca do opublikowania notki do wydania, z której wynikałoby, że „Kultura” odżegnuje się od treści poruszonych w tej szkodliwej książce. Jego wstręt do przetłumaczonej książki jest tak wielki, że zastrzega (w Post Scriptum dopisanym odręcznie): „Jeżeli dojdzie do wydania, to odmówię robienia korekty. Nie będę mógł wziąć do ręki tego tekstu".

W swojej krytyce książki Arona, Miłosz po raz kolejny wyrażał swą niezgodę na upraszczającą retorykę antykomunistyczną, na płaskość i powierzchowność rozwiązań oferowanych przez Zachód, a więc na ,zbywanie” poważnych problemów i debat współczesności zbyt łatwymi i banalnymi tezami. Uważał, że jeżeli Zachód tylko taką głębię miał do zaoferowania intelektualistom poszukującym i tym, którzy już zostali „ugryzieni” przez Heglizm, to książka ta przypieczętuje ostateczne rozczarowanie „wolnym światem, ${ }^{, 53}$.

\section{Loże prokrustowe, czyli o pewnym tekście Miłosza w „Forum”}

Obawy Miłosza dotyczące uczciwości Kongresu Wolności Kultury miały swoje głębokie uzasadnienie. Manipulacja i adaptacje tekstów dla potrzeb ideologicznych, skróty, przeinaczania znaczeń: wszystko to świadczyło, że przekaz musiał być jednoznaczny, ,skrojony” na konkretne polityczne potrzeby.

W 1959 r. Miłosz miał duże powody do złości. Austriacki organ Kongresu Wolności Kultury, czasopismo „Forum”, opublikowało na swoich łamach (i na dodatek rozdystry-

${ }^{53}$ Miłosz próbuje ponownie przekonać Giedroycia o szkodliwości książki Arona w swoim liście z lipca 1958, odnosząc się do ostrej, i słusznej według Miłosza, krytyki książki zamieszczonej w czasopiśmie „Dissent”. Na temat recepcji Arona przez Miłosza, por.: Na marginesie „Opium Intelektualistów” [Raymonda Arona]. Jerzy Giedroyc - Czesław Mitosz: listy, Nowe Sprawy Polityczne 2007 nr 32, s. 138-165. Podobnie o innym ulubionym myślicielu Giedroycia, Jamesie Burnhamie i jego wydanej przez „Kulturę” pozycji Bierny opór czy wyzwolenie (Paryż 1953, thum. J. Ulatowski), pisze Miłosz krytycznie, i w swoim długim liście do Giedroycia z marca 1956 kwalifikuje tę książkę jako pozycję „martwą” w dorobku wydawniczym „Kultury”. Następnie dodaje: „Nie tylko martwą, ale nawet przez swoją martwość szkodliwą, bo nie porusza żadnych poważnych problemów, nie reprezentuje zalet stylu i jest podrzędną pracą dziennikarską" (s. 254). 
buowało w siedmiu językach podczas Festiwalu Młodzieży Komunistycznej) tekst Miłosza bez jego zgody i autoryzacji. Chodziło o wykład Miłosza na Uniwersytecie Wolnej Europy, w lecie 1957 r., który następnie włączony został do publikacji książkowej L'Europe des dix pays absents: a collection of lectures, przygotowanej przez Bondy'ego. Miłosza rozwścieczyło przede wszystkim to, że thumaczenie tekstu odbiegało od pierwowzoru tak bardzo, że wyglądało wręcz na luźną adaptację oryginału.

W tej sprawie interweniuje u samego szefa Kongresu, Johna Hunta, pisząc do niego pełen oburzenia list w dniu 25 września 1959 r. (odnaleziony w Archiwum Kongresu w Chicago ${ }^{54}$ ). „Skandalem” i „,chirurgią” określa Miłosz sposób, w jaki „Forum” zrobiło użytek z jego tekstu. Miłosz stwierdza:

[...] Kongres jest odpowiedzialny za szkodę wyrządzoną przez jedno z jego czasopism. Wątpię, czy takie rzeczy powinny być tolerowane, jako że stoją one w oczywistej sprzeczności z wolnością słowa. Tekst z „Forum” został przejęty przez stacje radiowe Republiki Federalnej. Nie mogę nad tym zapanować — za późno. Wiesz dobrze, że to, co decyduje o jakości pisarstwa to przede wszystkim ton i niuans. Zmieniając ton nie mówiąc już o nonsensach dodanych przez „Forum” - można zmienić dany tekst w jego przeciwieństwo. Musimy być „formalistami”. Uważam, że nawet jedno zdanie usunięte przez wydawcę albo komisarza jest powodem, aby wszcząć piekło. W przeciwnym przypadku jakakolwiek walka $\mathrm{z}$ cenzurą jest niemożliwa ${ }^{55}$.

Jak wnioskujemy z odpowiedzi Hunta do Miłosza z 20 listopada 1959, Miłosz porównywał Kongres w innym (nie odnalezionym) liście do „wyspecjalizowanych agencji które walczą z komunizmem".

Na fali wzburzenia, 23 października 1959, Miłosz pisze także do szefa publikacji kongresowych, François Bondy’ego ${ }^{56}$. Mówi tam o swojej „wściekłości” (rage) na Torberga, redaktora naczelnego „Forum”, chociaż, jak wyraźnie zaznacza, ta wściekłość nie jest wymierzona ani w samego Bondy’ego ani w Kongres. Jednakże walczy w swym liście aby zrozumiano, że nie robi on ,much fuss about nothing” [sic! — tak w oryginale francuskim] i że „niuanse słów są ważne” („les nuances des mots comptent”). Następnie dodaje, że w swojej polemice z polskimi komunistami prowadzonej na stronach „Kultury” potrzebuje silnych kart, a w tym nie pomagają bynajmniej ,idiotyczne frazy” (,phrases idiotes”) zawarte w tekście opublikowanym przez „Forum”. Żąda żeby gazeta wydrukowała sprostowanie, które ma zawierać: po pierwsze, informację że tekst jest tłumaczeniem oryginału francuskiego z 1957 r.; po drugie, że tłumaczenie to autor uznaje za „mało wierne” (,peu fidele”); i po trzecie, że w związku z ominięciami całych fragmentów, jak i zamieszczenia odwrotnych znaczeń niż w pierwotnym tekście, autor „nie uważa żeby tekst opublikowany przez «Forum» odzwierciedlał ducha oryginału” (,il ne croit pas que le texte publié par «Forum» correspond a l'esprit de l'original"). Następnie wyjaśnia Bondy'emu, że jego wściekłość łatwo znajduje wytłumaczenie: „Forum” stworzyła wrażenie, iż jego artykuł napisany został oryginalnie po niemiecku i, na dodatek, na potrzeby Festiwalu Młodzieży

${ }^{54} \mathrm{IACF}, \mathrm{II} / 223$; f. 2.

55, ,...] the Congress is responsible for damage done by one of its publications. I doubt whether such things should be tolerated as they are in obvious contradiction with freedom of expression. The text from «Forum» was taken over by the radio stations of the Federal Republic. I cannot control this - too late. You know well that what decide of quality in writing is first of all the tone and the nuance. By changing a tone - without speaking of nonsenses [sic!] added by „Forum" - one can change a piece of writing into its opposite. We have to be «formalistic». I suppose even one sentence taken out by the editor or by a commissar should be enough to raise hell. Otherwise any fight against censorship is impossible".

${ }^{56} \mathrm{IACF}, \mathrm{VII} / 9$; f. 9. 
komunistycznej, co sytuuje go jako prokomunistę, i tak może zostać odebrane przez Warszawę. Ważne słowa mówi także Miłosz w Post Scriptum, gdzie przypomina, iż wobec ataków propagandy komunistycznej na Kongres, jego publikacje muszą zachować „linię stanowczą ale absolutnie czystą" (,une ligne ferme mais absolument nette").

W swoim ostrym liście do „Forum”, którego kopię załącza do wrześniowego listu do Hunta, Miłosz wylicza punkt po punkcie sposoby, w jakie czasopismo naruszyło jego prawa. Dla Miłosza, znacznie istotniejsza niż kwestia braku zgody na publikację, była sprawa zmian treściowych. Przede wszystkim, uderza zmiana tytułu z oryginalnego $D e$ quelques problèmes de la jeunesse contemporaine na Das Ende ser Verzweiflung (na okładce) i Das Ende der Apokalypse (wewnątrz numeru) [tam gdzie to konieczne, zachowujemy pisownię oryginału tego listu]. Miłosz wskazuje na usunięcie całych fragmentów, dodanie śródtytułów, i stwierdza, że tekst jest adaptacją, nie zaś tłumaczeniem oryginału.

Niektóre zdania powstają w głowie waszego thumacza. W innych, dodawane są przymiotniki z widoczną intencją dorzucenia taniej gazeciarskiej ironii, której nie ma w moim tekście ${ }^{57}$.

Pomimo iż mówi, że przykładów jest za wiele, aby można je było wymienić, podaje jednak kilka, które dobitnie ukazują manipulację popełnioną przez redakcję „Forum”:

I say „Doctor Goebbels”, Forum: „kleine Doctor Goebbels”; I say: „Bertolt Brecht”, you „Sein Landsman Bertolt Brecht”; I say „l'efficacité”, you „teuflische Wirksamkeit”; I say ,la dialectique des relations humaines (sans aucune nuance émotive, avec une nuance légère plutôt favorable)”, you „die zwielichtige Dialectik in den menschlichen Beziehungen”; I say „la meme ornière”, you „die gleiche schiefe Bahn”; I say ,je ne suis pas d'accord avec ceux qui pretendent que l'ideologie ne compte pas”, you „Ich gehöre nicht zu jenen, die den Komunismus als Ideologie für bedeutunglos halten"where I speak of ideology in general, your translator puts, obviously, „Kommunismus”.

Dalej podkreśla: „co gorsza, są całe paragrafy których sens został zmieniony na d o k ład n i e odwrotny niż w oryginale" (,what is even worse, there are passages with a sense exactly opposite to the sense of the original"), jak w przypadku kiedy to słowa młodego komunisty polskiego, który z pełną wiarą i w żadnym wypadku nie dla kariery (,Ce n'est sans doute pas pour faire une carrière que j'ai passé plus d'une nuit blanche [...]") próbował budować socjalizm w Polsce, zostają przeinaczone w taki sposób, że młody ten dziennikarz robi to wszystko właśnie dla kariery („Nur um Karriere zu machen habe ich die Nachte durchstudiert...”). Kończąc list Miłosz podsumowuje:

Konkludując, wyrządziliście wielką szkodę mojemu imieniu zmieniając mój tekst, napisany z precyzją i bez żadnych grzmiących przymiotników zdolnych do zranienia ludzkich uczuć, w rutynowy zimnowojenny artyku1 ${ }^{58}$.

Zmieniając tekst Miłosza w zimnowojenny prefabrykat, „Forum” popełniło manipulację, którą bezsprzecznie można porównać do aktu cenzury wobec wolności myśli Miłosza $^{59}$.

57 „Some sentences come from the head of your translator. In others, adjectives are inserted, with a visible intention of providing some cheap newspaper irony lacking in my text".

58 „In conclusion, you did a great damage to my name through changing my text written with precision and without any blaring adjectives able to wound human feelings into a routine cold war article".

${ }^{59}$ Nie pierwszy raz walczył Miłosz o integralność swoich tekstów. W swym liście do Giedroycia wspomina inny swój artykuł, Adam Mickiewicz, opublikowany w „Russian Review” (1955 nr 4, s. 322-331), w którym zaprotestował po tym jak redakcja tego czasopisma wykreśliła 


\section{KILKA WAŻNYCH UWAG O KONGRESIE WOLNOŚCI KULTURY}

Przytoczone przykłady korespondencji Czesława Miłosza zmuszają do pewnej refleksji nad istotą Kongresu Wolności Kultury. W kolejnej części tych rozważań, przybliżymy naturę i sposób działania Kongresu, naświetlimy problem finansowania i jego związek z CIA, poruszymy problem relacji z intelektualistami oraz rozpatrzymy kwestię ich zaangażowania i wolności w ramach współpracy $\mathrm{z}$ tą organizacją.

\section{O związkach z Agencją}

Kongres odniósł względny sukces w prezentowaniu się przez lata, a szczególnie w latach 60., jako forum poszanowania wolności i swobodnego przepływu idei. Sukces ten wynikał z dwóch przyczyn. Po pierwsze, był to wynik działań Michaela Josselsona, agenta CIA i spiritus movens Kongresu. Josselson był agentem niezależnym, i nawet krytyczna wobec Kongresu badaczka Frances Stonor Saunders wskazuje na jego zasługi w obronie integralności Kongresu i fakt, że przez lata próbował go całkowicie uniezależnić od funduszy Agencji (z nieudanym zresztą skutkiem) ${ }^{60}$. Josselson miał ułatwione zadanie, gdyż wielu członków Agencji popierało i utożsamiało się z socjaldemokratycznym liberalizmem Kongresu (czym narażali się nawet na prześladowania senatora McCarthy'ego). Z drugiej strony, sukces wynikał ze szczególnej dbałości waszyngtońskiej centrali o względną integralność atmosfery intelektualnej skupionej wobec Kongresu. Nie było to jednak bynajmniej przejawem miłości do samej wolności kultury i myśli. W rzeczywistości chodziło o subtelną strategię sformułowaną przez Toma Bradena, szefa komórki CIA odpowiedzialnej za Kongres, w jednej ze swych instrukcji do szefów Kongresu w Europie: „[należy] chronić integralność organizacji, [którą próbuje się objąć kontrolą i wpływem] nie wymuszając na niej, żeby popierała wszystkie i każdy jeden z celów oficjalnej polityki amerykańskiej" ${ }^{61}$.

Nawet najwięksi zwolennicy Kongresu zdają sobie sprawę, że wątek szpiegowski pojawiający się zarówno w jego genezie, jak i samej działalności, stanowi problem, biorąc pod uwagę elementarną logikę. Oto bowiem mamy przed sobą ogromną, niemal wszechpotężną instytucję wydającą przez długie lata dziesiątki prestiżowych gazet, tysiące książek, finansującą konferencje i seminaria na całym świecie, rozdającą stypendia dla obywateli krajów zniewolonych przez dyktatury, wszystko to w imię ,,wolności kultury"; jednak finansowaną z budżetu departamentu CIA w ramach covert action. Pod koniec lat 70., Komitet Churcha (Church Committee), badający temat infiltracji CIA i FBI w rozmaitych ,niezależnych” instytucjach na całym świecie, zdefiniował termin covert action jako ,tajne działanie mające na celu wywarcie wpływu na rządy, wydarzenia, organizacje lub jednostki w innych krajach, w kierunku poparcia polityki zagranicznej Stanów Zjednoczonych, realizowane w taki sposób, aby udział Stanów Zjednoczonych był niewidoczny"62 . Dylemat jak może być promowana wolność przez siły, na które żadnego wpływu nie ma demokratyczna opinia publiczna

wzmianki o socjalistycznych sympatiach Mickiewicza w okresie Trybuny Ludów. Konstatuje do Giedroycia: „Tym Amerykanom zajączki biegają już po głowie, jeżeli boją się nawet słowa «socjalizm»" (list z września 1955, s. 233-234).

${ }^{60}$ F. Stonor Saunders, Who paid the piper?, s. 340, 498.

${ }^{61}$ Tamże, s. 145 (wywiad F. Stonor Saunders z Tomem Bradenem).

${ }^{62}$ Tamże, s. 65 (National Security Council Directive 10/2: dyrektywa przytoczona w Końcowym Raporcie Komitetu Churcha, 1976). 
i które pociągają sznurkami w sobie tylko wiadomym kierunku pozostał nierozstrzygnięty. Scott Smith określa związek miedzy CIA i Kongresem mianem „instrumentalnego liberalizmu", i definiuje go jako taki typ liberalizmu, który

stworzony, aby działać w obronie wolności demokratycznych, [czyni to] w sposób, który wydaje się że podkopuje fundamenty [undermine] owych wolności, ale który uważany był za potrzebny ze względu na zagrożenie związane z sytuacją Zimnej Wojny ${ }^{63}$.

Utajnienie źródeł finansowania i faktycznych celów organizacji związane było więc bezpośrednio z pragmatyzmem akcji kontrapropagandowej.

Oskarżenia dotyczące źródeł finansowania Kongresu były systematycznie wysuwane przez komunistów i stały się największym problemem tej organizacji. Oczywiste jest to, że wielu współpracowników Kongresu albo wiedziało albo podejrzewało, że ogromne pieniądze Kongresu musiały mieć jakiś związek z amerykańskimi strukturami rządowymi. Szef Kongresu i agent CIA John Hunt, jak również wdowa po Michaelu Josselsonie i była agentka, Diana Josselson, nie mieli wątpliwości, że finanse Kongresu były tajemnicą poliszynela wśród większości intelektualistów, którzy współpracowali z Kongresem. Hunt mówi otwarcie o współpracujących intelektualistach: „Wiedzieli, i wiedzieli tyle, ile chcieli wiedzieć, i gdyby wiedzieli więcej, wiedzieli, że musieliby odejść, dlatego nie chcieli wiedzieć” ${ }^{\circ 4}$. Jeden $\mathrm{z}$ fundatorów Kongresu, Amerykanin Sydney Hook, mówi: „nie miałem najmniejszych wątpliwości, że CIA w jakiś sposób przyczyniała się do finansowania Kongresu... Wszyscy zaangażowani w działalność Kongresu słyszeli pogłoski o ukrytym wsparciu CIA"65. Czesław Miłosz pisze jednak, że nikt ze współpracujących z Kongresem intelektualistów nie wiedział o finansowaniu przez CIA, choć przyznaje, ,że na milę niosło odorem dużych pieniędzy" ${ }^{\prime 66}$. Podejrzewamy, że prawda znajduje się gdzieś pośrodku. W 1967, gdy wybuchł skandal o tajnym finansowaniu Kongresu, wielu jego współpracowników na całym świecie poczuło się zdradzonych i ogłuszonych tymi informacjami, jak choćby długoletni szef „Encountera", Stephen Spender, czy liberalni intelektualiści antyfrankistowscy w Hiszpanii.

Pomijając kwestię, kto wiedział i kto nie, nawet ci współpracownicy Kongresu, którzy podejrzewali skąd pochodziły pieniądze, czuli się wolni od wszelkiej polemiki. Związki z CIA nie zostały upublicznione aż do roku 1967. Z drugiej strony, wielu z nich podzielało zapewne opinię, że dopóki trybuna, z której głosili swoją prawdę nie była manipulowana, kwestia tego kto utrzymywał tę trybunę była drugorzędna. Podkreśla to Giles Scott Smith mówiąc, że aby zrozumieć Kongres należy rozważać jego działalność $w$ określonym kontekście historycznym ${ }^{67}$. Rhodri Jeffreys-Jones idzie w swej analizie jeszcze dalej i powątpiewa, czy w latach 50. wiadomość o finansowaniu przez CIA spowodowałaby skandal, który owszem wybuchł w znacznie bardziej zrelaksowanej politycznie dekadzie lat $60 .^{68}$ Dlatego też, aby dogłębnie zrozumieć Kongres Wolności Kultury, należy wyjść poza relacje na linii Agencja-Kongres i poza sam problem jego finansowania.

\footnotetext{
${ }^{63}$ G. Scott Smith, The Politics of Apolitical Culture, s. 80.

${ }^{64}$ Wywiad F. Stonor Saunders z Johnem Huntem, [w:] F. Stonor Saunders, Who paid the piper?, s. 550.

${ }^{65}$ G. Scott Smith, The Politics of Apolitical Culture, s. 163.

${ }^{66}$ Cz. Miłosz, Abecadto, s. 100.

${ }^{67}$ G. Scott Smith, The Politics of Apolitical Culture, s. 164.

${ }^{68}$ R. Jeffreys-Jones, The CIA and American Democracy, Londres 2003, s. 87.
} 


\section{O celach i metodach}

Głównym celem działalności Kongresu było zneutralizowanie wpływu marksizmu i prokomunistycznych sympatii wśród intelektualistów na całym świecie. Ta kwestia stawała się szczególnie paląca w krajach trzeciego świata, które właśnie wyswobadzały się spod wpływu kolonialnych mocarstw Zachodu. Narody i elity Azji, Afryki i Ameryki Południowej były szczególnie „uodpornione” na idealizowanie zachodnich demokracji i przez to podatne na (wybiórcze) poparcie dla „antyimperialistycznej” polityki prowadzonej przez Nikitę Chruszczowa. Oczywiste było to, że tylko lewicowcy mówią językiem innych lewicowców i że argumenty prawicowe nie znalazłyby żadnego posłuchu wśród środowisk, na które Kongres, i przez niego CIA, chciało oddziaływać. Poza tym, zbytnie sympatie na prawo mogły łatwo stać się pretekstem do jeszcze bardziej zaciekłych ataków na Kongres ze strony propagandy sowieckiej. Aby przekonać nie przekonanych i sceptycznych, należało dysponować przekonującą ,,artylerią ideologiczną”.

Kongres obrał więc jako swój główny nurt ideologiczny „liberalizm” rozumiany na modłę amerykańską (termin, który w Europie miałby swój odpowiednik w ideałach lewicy socjaldemokratycznej). Współpracownicy należeli do antystalinowskiej lewicy rewolucyjnej, lewicy liberalnej, byli byłymi komunistami lub federalistami europejskimi. Zbyt prawicowi i jawnie antysocjalistyczni fundatorzy Kongresu, jak James Burnham, Arthur Koestler, Melvin Lasky i wielu innych, jak choćby szefowie jego lokalnych struktur w krajach Ameryki Południowej (zbyt emocjonalnie antykomunistyczni), byli konsekwentnie usuwani ze struktur Kongresu, a także jego wydawnictw i działań ${ }^{69}$.

W związku z odgórną próbą kontroli panującą w Kongresie, czasami dochodziło także do dezercji z jego struktur. Najgłośniejszą z nich była rezygnacja z piastowania funkcji Honorowego Prezydenta przez Bertranda Russella, ulegając w końcu w 1952 namowom swej przyjaciółki Hannah Arendt, która przez lata przestrzegała go przed oficjalnym „figurowaniem” w strukturach Kongresu. Inni, jak Dwight McDonald i Sidney Hook, nigdy nie dostali możliwości kierowania „Encounterem”, ponieważ byli politycznie nieobliczalni bądź nieprzydatni ${ }^{70}$. W dofinansowywaniu planów wydawniczych „Kultury”, decyzja o daniu pierwszeństwa publikacjom Miłosza (która zapadła oczywiście poza nim), ilustruje świetnie pragmatyzm, z jakim działał Kongres, biorąc pod uwagę trudną sytuację innych polskich pisarzy emigracyjnych.

Szczególnie uderzające jest jak dalece instrumentalne było traktowanie współpracujących z Kongresem intelektualistów i twórców. W swym liście do szefa Fundacji Farfield, 7 września 1954, Nicolas Nabokov prosi o finansowe wsparcie dla polskiego kompozytora Andrzeja Panufnika po jego ucieczce z kraju. W liście tym mówi Nabokov, że Panufnik jest całkowicie oddany ideałom Kongresu (,,he is entirely ready to cooperate and collaborate with us for he is entirely sold on the ideals of the Congress for Cultural Freedom”) i wskazuje, że jeżeli Kongres wyciągnie pomocną rękę do Panufnika, „zdobędziemy szalenie przydatnego stałego przyjaciela Kongresu (,,an extremely useful permanent friend for the Congress"), który może stać się równie ważny dla nas, jak w pierwszym roku naszej działalności" Czesław Miłosz ${ }^{71}$. Na przykładzie tego

${ }^{69}$ O przykrych i frustrujących doświadczeniach Jerzego Giedroycia z Kongresem Wolności Kultury warto by napisać osobne studium. Jak wiemy Giedroyc zawsze odnosił się do Kongresu z rezerwą i „Kultura”, pomimo propozycji w tym kierunku, nigdy nie stała się czasopismem tej organizacji.

${ }^{70}$ Por.: G. Scott Smith, The Politics of Apolitical Culture, s. 152; Cz. Miłosz, Abecadto, s. 207.

${ }^{71}$ G. Scott Smith, The Politics of Apolitical Culture, s. 163. 
listu Scott Smith pokazuje mechanizm działania Kongresu: chęć pomocy łączyła się zawsze $z$ interesem własnym organizacji. I rzeczywiście, w Kongresie najważniejszy był zawsze pragmatyzm. W momencie, gdy zmieniała się koniunktura polityczna, bezpardonowo pozbywano się niewygodnych współpracowników albo ograniczano ich obecność w przedsięwzięciach i publikacjach Kongresu.

Pragmatyzm nie dotyczył wyłącznie doboru współpracowników, lecz odnosił się także do rodzaju i charakteru poruszanych tematów. Także tutaj najważniejsza była strategia. Jak wynika $\mathrm{z}$ rozmaitych dokumentów, na które natrafiłam w badaniach archiwalnych $^{72}$, walka Kongresu z prawicowymi dyktaturami (Peron czy Trujillo w Ameryce Południowej lub Franco w Hiszpanii) była prowadzona przede wszystkim jako pretekst dla efektywniejszej walki z komunizmem. Chodziło po prostu o to, żeby w oczach lewicowej opinii publicznej zapewnić wiarygodność Kongresu jako organu walki z wszystkimi, także prawicowymi, dyktaturami. Chodziło także o wytrącanie argumentów propagandzie sowieckiej, która przez cały okres działania Kongresu, oskarżała go o proamerykański imperializm (Stany Zjednoczone aktywnie wspierały w tamtych latach prawicowe dyktatury na całym świecie).

Sam sposób „ustawiania” tematów i debat, które podnoszone były na forum Kongresu, klucz, według którego dobierani byli jego współpracownicy, instrumentalne ich traktowanie, przykre zmiany personalne, akty cenzury popełniane $\mathrm{w}$ redakcjach gazet kongresowych wobec swoich najważniejszych nazwisk, nieobecność bądź sztuczne wyciszanie niewygodnych tematów: wszystko to niewiele miało wspólnego z realizacją idei „wolności kultury”. Światli współpracownicy, jak choćby Czesław Miłosz i Dwight McDonald, byli doskonale świadomi istnienia tej ciemnej strony Kongresu.

\section{Władza i Prawda, czyli kolejny dramat intelektualisty XX wieku}

McDonaldowi zawdzięczał Miłosz znaczną część swojego politycznego wykształcenia, i pisał o nim w Abecadle, że ,toczył wojnę ze wszystkimi”, zajmował się przez całe życie ,,poszukiwaniem własnych przekonań” i był miotany sprzecznościami, które są „ceną, jaką płaci się za całkowitą niezależność postawy”73. Amerykański intelektualista tak opisywał kongresowe czasopismo „Encounter”, już po wybuchu skandalu w związku z finansowaniem:

Podczas gdy „Encounter” zawsze denuncjowało pożyteczne kłamstwa, dzięki którym utrzymywały się reżimy komunistyczne, nigdy nie było naprawdę wolne od ,pułapki ideologii”, od owej dominującej mentalności zimnej wojny „kłamania w imię prawdy”. „Zachowując ciszę" na temat polemicznych i palących problemów, ze względu na nad-

72 Przykładem może być dokument zatytułowany „Deuxième rapport sur Chili”, Louisa Merciera, z 27 kwietnia 1953 (IACF, II/204; f. 7). Mercier był specjalnym wysłannikiem Kongresu do krajów Ameryki Południowej. Pisze w nim, że aby „podbić” lewicujących intelektualistów Ameryki Łacińskiej, Kongres musi przedstawiać się jako potępiający prawicowe i neofaszystowskie dyktatury, na marginesie antykomunistycznego „prania mózgu”: „Aussi, une place doit être accordée, a côté de la campagne permanente de débourrage de crânes sur la réalité soviétique, a l'information sur l'Espagne franquiste, sur les régimes militaires d'Amérique Latine, même s'ils son soutenus par certaines «machines» nord-américaines, sur les luttes menées aux Etats- Unis avec notre participation contre le discrimination racial et le McCarthysme par exemple".

${ }^{73}$ Cz. Miłosz, Abecadło, s. 204-206. 
miar dyplomacji i trzymania w ukryciu wszystkich zafałszowań i mierności, które na przestrzeni lat narosły w naszym środowisku intelektualnym ${ }^{74}$.

W zderzeniu Zachodu ze Wschodem, chodziło o poparcie Zachodu, ale krytyczne i ambitne: tak było w przypadku Miłosza i było też tak w przypadku McDonalda. Obaj nie wyrażali zgody na typ języka, którym często posługiwano się na łonie Kongresu, na ową specyficzną ,retorykę wolności”, która przypominała zbyt często żargon czysto propagandowy. Obawiali się też, że ich myśli i idee zostaną sprowadzone do pragmatyzmu akcji kontrapropagandowej, zgodnie $\mathrm{z}$ tezami i ideami nie zagrażającymi (i, w perspektywie wieloletniej, pomagającymi) polityce amerykańskiej. Obawa, żeby nie zostać wykorzystanymi do celów propagandy była wśród największych nazwisk Kongresu jak najbardziej żywa i dobitnie przekonuje o tym korespondencja Miłosza.

Jednak wielu intelektualistów, nawet jeśli sami byli sceptyczni i pełni obaw, broniło Kongresu na forum publicznym. Bali się oni porażki jego akcji i działań, ponieważ uważali za konieczne dać zorganizowany odpór sowieckiej propagandzie. Fakt ten nie powinien jednak oznaczać, że kilkadziesiąt lat później jesteśmy zmuszeni do takich samych ustępstw. Tą dwoistość między publicznym dyskursem i ukrytymi obawami świetnie ilustruje przykład Ignazio Silone, długoletniego szefa włoskiego organu Kongresu, jakim było „Tempo Presente”. Silone prawie odmówił pojechania na inauguracyjne spotkanie Kongresu do Berlina w 1950, ponieważ obawiał się wzięcia udziału w propagandowym spektaklu. Pomimo to, w swojej mowie wygłoszonej na tym Kongresie podkreślał, że spotkanie to nie jest nowym rozdziałem Zimnej Wojny i, że jest to po prostu spotkanie ,wolnych ludzi”, którzy czują się zobowiązani do „swobodnego mówienia prawdy" w tak trudnym historycznie okresie ${ }^{75}$.

$\mathrm{Na}$ początku pisaliśmy o podwójnej genezie Kongresu Wolności Kultury. Jako twór intelektualny i społeczny (a nie polityczny, związany z organami strategii amerykańskiej), Kongres powstał $\mathrm{z}$ pozytywistycznego przekonania o potrzebie wpływu intelektualistów na rzeczywistość, która ich otacza. Choć podążał tą XIX-wieczną tradycją, przez swój związek z konkretną strukturą władzy Stanów Zjednoczonych, oznaczał zarazem jej dramatyczną transformację:

Kongres powstał w czasie, kiedy tradycyjna pozycja autonomicznego, krytycznego intelektualisty była zagrożona $\mathrm{w}$ związku $\mathrm{z}$ wymogami politycznego konformizmu na Wschodzie i Zachodzie, i był w pewnym sensie odpowiedzią na te warunki. Jednak zachodzi tutaj podwójna sprzeczność. Po pierwsze, paradoksalne mogłoby wydawać się stworzenie instytucji, której celem ma być ochrona tożsamości tradycyjnej, niezależnej inteligencji. Po drugie, podczas gdy Kongres Wolności Kultury przedstawiał się jako strażnik wolnomyślącej inteligencji, spełniał tę funkcję z głęboko politycznym celem. Zainteresowanie CIA wobec tej organizacji, wynikało przecież z możliwości monopolizacji idei wolności intelektualnej w walce prowadzonej w ramach Zimnej Wojny ${ }^{76}$.

W przypadku Kongresu, to nie kwestia finansowania jest najbardziej polemiczna. Dzisiaj jasne i trudne do przemilczenia jest przede wszystkim to, że Kongres w praktyce był daleki od realizacji na „własnym podwórku” nadrzędnej idei, z którą obnosił się we

${ }^{74}$ Słowa Dwighta McDonalda cyt. w: M. Wreszin, A Rebel in Defense of Tradition: The Life and Politics of Dwight McDonald, New York 1994.

${ }^{75} \mathrm{G}$. Scott Smith, The Politics of Apolitical Culture, s. 112.

${ }^{76}$ Tamże, s. 13. 
wszystkich swych publikacjach i aktach: idei wolności intelektualnej. Znacznie bardziej polemiczny niż kwestia funduszy, był fakt, że przez lata działalności Kongresu miała miejsca interwencja i, czasami manipulacja, ideami i myślą jego współpracowników. Zbyt często wolność kultury w publikacjach Kongresu utożsamiała się z realizacją podstawowych założeń polityki zagranicznej Stanów Zjednoczonych. Efekty tej polityki widoczne są zresztą do dziś. Kongres przyczynił się do wielu jednoznacznie pozytywnych zjawisk, takich jak upadek Związku Radzieckiego i przygotowanie do demokracji elit społeczeństw zza żelaznej kurtyny (przez szeroką akcję opiniotwórczą i stypendia). Byłoby jednak głęboką naiwnością i niekompetencją wybiórcze analizowanie jego działalności i zastąpienie rzetelnej oceny nieumiejętnością racjonalnego zważenia dobrych, ale także i złych skutków działalności Kongresu, jako instrumentu zimnej wojny.

Jeżeli chodzi o samych współpracowników Kongresu, to ci, którzy uznali konieczność prowadzenia kontrofensywy ideologicznej za swoją powinność w dobie zimnej wojny, wplątali się w zasadniczy konflikt relacji intelektualistów do władzy, na który zwrócił już uwagę Michel Foucault. Pisał on o konceptach prawdy i władzy, że „Prawda jest połączona kolistym związkiem z systemami władzy, które ją wytwarzają i ją podtrzymują, i do instrumentów władzy, które powoduje i które ją rozpowszechniają"77. Za najbardziej niekorzystny skutek kulturalnej i ideologicznej zimnej wojny, prowadzonej przez Związek Radziecki i Stany Zjednoczone, uznać należy trwające pięćdziesiąt lat wyjałowienie i spolaryzowanie debaty publicznej. Efekty tego wyjałowienia debaty i skażenia języka widoczne są zresztą do dziś. To miało (i ma) dla wolnej myśli stosunek jednoznacznie negatywny, jak każda próba odgórnej ingerencji w wolność przepływu myśli oraz idei, i neutralizacji nonkonformistycznej inteligencji.

Wielu intelektualistów, którzy zaangażowali się w działalność Kongresu, ponieważ czuli, że mogą w ten sposób służyć ideom uniwersalnym, takim jak Wolność czy Prawda, niepostrzeżenie przekroczyło linię i sprowadziło swą misję, tout court, do zaangażowania w imię wolności i prawdy Stanów Zjednoczonych. Tego kolejnego dramatu intelektualistów XX w. udało się jednak uniknąć Czesławowi Miłoszowi.

\section{4. „PRAWDA I SPRAWIEDLIWOŚĆ” CZESŁAWA MILOSZA}

Po latach Miłosz mówił:

Zimna wojna, przeciwstawiając demokratyczną Amerykę i ponury wschodni totalizm, odejmowała wielu ludziom swobodę sądu i jasność widzenia, skoro brak entuzjazmu dla Ameryki mógł uchodzić za przechylanie się na komunistyczną stronę ${ }^{78}$.

Brak entuzjazmu dla Stanów Zjednoczonych widoczny jest choćby w Abecadle i w Roku myśliwego, zaś odżegnywanie się od „sfery strategii i taktyki” (jak rozumiał politykę) i od antykomunistycznej dywersji w całej twórczości noblisty. W swoich listach, Miłosz wielokrotnie przestrzegał szefa „Kultury” przed uprawianiem kontrpropagandy, czyli zniżaniem się do poziomu retoryki zimnowojennej, tak ze względów „,moralnych” — gdyż manicheistyczna wizja świata nie pokrywa się z prawdą — jak i ,praktycznych”, czyli pragmatycznych (Listy, list z maja 1959, s. 344-345). W swej współpracy

${ }^{77}$ Słowa M. Foucault, pochodzące z jego książki Power/Knowledge: Selected Interviews and Other Writings 1972-1977 (Brighton 1980) cyt. za: G. Scott Smith, The Politics of Apolitical Culture, s. 112 [ttum. - O. G.].

${ }^{78}$ Cz. Miłosz, Abecadto, s. 36. 
z Kongresem, Miłosz zawsze zachował swoje prawo do wypowiadania własnej prawdy i do sprawiedliwego oddania prawdy innych.

\section{Pułapki pamięci, czyli Czesława Miłosza rozliczenia ze sobą}

Jak po latach Miłosz oceniał swoje wybory i postawę w czasach zimnowojennych? Przybliżonej odpowiedzi na to pytanie dostarczają książki, które napisał, gdy był już starszym człowiekiem.

W Roku myśliwego, książce, którą miała mu pomóc „zrozumieć” własne życie, widać, że Miłosz nie lubi już swych cech „prawdziwego Litwina”: dawnego uporu podejrzliwości, skąpości i ostrożności ${ }^{79}$. Wyczuwa się pewne zmęczenie, przejawiające się w „okrągłych” frazach o religii (gdzie wspomina, że nawet Zniewolony umyst „,począł się z modlitwy”) lub w opracowywaniu rejestru swych „błędów”, rozumianych jako pewne postawy w przeszłości. Mówi o swoich zaletach, które podejrzewa, że są wynikiem jego starości — „pobłażanie i cierpliwość” — i z przykrością wspomina „o swoich dawnych fanatycznych wymaganiach, furiach, złych humorach" ${ }^{\text {" Czytając }}$ Rok myśliwego odnosi się wrażenie, że Miłosz nie lubi także swego dawnego dialektyzmu i relatywizmu, jako metod poznania i rozumowania. Z kolei, w rozmowach z Fiutem, wspomina okres powojenny w Polsce jako czas, kiedy „uprawiał prostytucję sprowadzając całą głębokość problematyki wyrażonej w Zniewolonym umyśle li i jedynie do problemu oportunizmu i konformizmu.

Dawne spory prowadzone przez lata, nagle wydają się Miłoszowi bezzasadne i przyjmuje, że były one pochodną popełnionych przez niego błędów. W Roku myśliwego wspomina swoje dyskusje i kłótnie z Czapskim i przypisuje je tylko swojej winie: bądź ,zanieczyszczeniu” swego umysłu, bądź „defektom” jego charakteru i umysłu, oraz swej „dialektycznej” nieufności do „tak-tak, nie-nie” 82 . Pisze także gorzko o swej poezji, która nie była krzykiem przeciw zbrodniom XX w.:

A moja poezja? Chciałem krzyczeć, ale równocześnie wiedziałem, że krzyk jest nieskuteczny. Czując się winien, że nie krzyczę ${ }^{83}$.

W Abecadle wspomina Manesa Sperbera, autora recenzji Zdobycia władzy, na którego ideologiczną interpretację swej powieści niegdyś nie wyraził zgody. Tego „przekonanego antykomunistę" stawia po latach w rzędzie tych, którzy mieli odwagę i pasję ,powiedzenia czy wykrzyczenia prawdy wbrew zamkniętym na nią uszom zachodniej opinii”. Dalej zauważa, że „w samej chęci zostawiania świadectwa był element ofiary", rozumianej nie w kategoriach moralnych, lecz takiej, która związana jest z jakością samej twórczości literackiej:

Poważny pisarz celuje w przyszłość i jest dość wybredny, żeby nie babrać się w aktualności. Ale tak miało się złożyć, że z gniewu na upadlanie i dręczenie ludzi niektórzy wykraczali poza tę zasadę, czyli godzili się na przegraną — a jak miało się okazać, dotknęli spraw o nie tylko doraźnym znaczeniu ${ }^{84}$.

\footnotetext{
${ }^{79}$ Tenże, Rok myśliwego, s. 23.

${ }^{80}$ Tamże, s. 84, 94.

${ }^{81}$ A. Fiut, Czestawa Mitosza autoportret, s. 339.

${ }^{82}$ Cz. Miłosz, Rok myśliwego, s. 252.

${ }^{83}$ Tamże, s. 102.

${ }^{84}$ Cz. Miłosz, Abecadło, s. 297-299.
} 
Przywołuje także Sidneya Hooka, jedną z tych osób, które wykluczono z kierownictwa Kongresu za zbytnią bezkompromisowość: „Wydawał mi się umysłem suchym i zaciekłym. Z perspektywy widzę, że powinno mu się złożyć hołd za jego zaciekłość. Był fanatykiem rozumu i nienawidził kłamstwa [...]". Opisując stosunki Sidneya Hooka z paryskim Sekretariatem Kongresu, kwalifikuje je jako: „dzieje zmieniającej się taktyki wobec wschodniej ideologii”. Ciekawe, że po latach, uznaje stanowisko Hooka jako bardziej „wyważone” niż środowisko lewicy niekomunistycznej skupionej w Sekretariacie Kongresu, która „oportunistycznie” przyjmowała antyamerykański dyskurs, żeby zbliżyć się do nastroju elit europejskich, na które chciała wywrzeć wpływ ${ }^{85}$. Podobnie zmienia się jego ocena Jeleńskiego i Giedroycia:

W jego [Jeleńskiego] licznych starciach z Jerzym Giedroyciem najczęściej trzymałem jego stronę. Teraz opowiedziałbym się raczej za twardością Giedroycia niż za giętkością Kota. Nawyki lewicowe pozwalały Kotowi włączać się w paryskie intelektualne środowisko, ale też płacił cenę, ulegając masowym pędom ${ }^{86}$.

Znamienne jest to, że w miarę jak Miłosz dokonuje (kolejnego) krytycznego rozprawienia się ze swoim życiem, pomocna jest mu w tym pamięć o ludziach, z którymi dawniej się nie zgadzał. Abecadło było pisane przez Miłosza tak, aby pisząc o innych, mógł zarazem pisać o samym sobie. Odnosząc się idealistycznie do swych dawnych oponentów - wskazując na ich umiejętność krzyku w imię uciśnionych (Czapski), dotarcia do prawdziwej głębi (Manes Sperber), zaciekłość w obnażaniu kłamstwa (Hook) i twardość postaw (Giedroyc) — pognębiał zarazem Miłosz samego siebie. Nagle to, co dawniej uważał za właściwe i etyczne, czyli dociekanie skomplikowanej natury prawdy i dbałość o oddanie autentyczności opisywanego świata, ustępuje pochwale myśli prostej i dosadnej.

Kiedy czytamy, że prominentny członek Sekretariatu, Kot Jeleński, padał ofiarą „masowych pędów”, które to jednak pomagały mu włączyć się w intelektualne środowisko Paryża, i że Sekretariat Kongresu przyjmował oportunistycznie antyamerykański dyskurs, żeby zbliżyć się do nastroju elit europejskich, trudno nie uznać tej interpretacji za próbę rozliczenia się z hipokryzją działania Kongresu Wolności Kultury. Miłosz rozumiał, że zbyt często pragmatyzm polityczny powodował pójście na ustępstwa w pewnych podstawowych kwestiach, co wielokrotnie wiązało się z marginalizowaniem tych, którzy nie byli skłonni podpisać się pod ustępstwami w imię „,wolności kultury".

Problem Kongresu nie jest jednak problemem Miłosza. Popełnia Miłosz błąd porównując się z ludźmi takimi, jak Czapski, Hook, Sperber czy Giedroyc. Popełnia także niesprawiedliwość, negatywnie oceniając siebie na fali tego porównania (co wyczuwalne jest między wierszami przytoczonych fragmentów). Istota Miłosza, jego esencja jako pisarza-metafizyka, a nie moralisty, jest zupełnie inna. Pisząc o sobie: „Dajmy na to, że moja obecna świadomość jest jasna i, że z litością i grozą pochylam się nad fazami moich zaćmień”, Miłosz uznaje, że to właśnie te zaćmienia są przestrzenią duchową (,w mrocznych korytarzach głupoty”), w której narodziło się wiele jego wierszy $^{87}$.

\footnotetext{
${ }^{85}$ Tamże, s. 149.

${ }^{86}$ Tamże, s. 161.

${ }^{87}$ Tamże, s. 321-322.
} 


\section{Jak angażował się Czesław Miłosz, czyli o stylu i treści}

Pytania czy Miłosz był pisarzem niezaangażowanym oraz skąd się bierze jego polityczny desengagement $\mathrm{w}$ epoce ogólnego engagement są istotne. Na niezależną postawę Miłosza i brak jego zgody na pisanie rozmaitych tekstów na potrzeby aktualnej sytuacji politycznej w kraju, Marek Kornat nie znajduje jasnego wytłumaczenia ${ }^{88}$. Jednak sam Miłosz wyjaśnia w swoim liście z grudnia 1964 do Giedroycia, że jego niechęć „zaangażowania się” politycznego nie jest apolitycznością w ogóle, lecz w pewien specyficzny, zimnowojenny sposób (polegający na pisaniu odezw, apeli, deklaracji, działalność w stowarzyszeniach, itp.). Dodaje następnie:

Musisz zrozumieć, że moje myślenie nie jest apolityczne, a tym samym nie jest w sprzeczności z Twoim myśleniem. Każda epoka jednak wymaga innych środków.

Dzisiaj jest epoka, kiedy to, co wydaje się jak najmniej polityczne, jest naładowane różnymi potencjalnościami, także politycznymi, na przyszłość ${ }^{89}$.

Aby spróbować zrozumieć sposób, w jaki angażował się Czesław Miłosz, szczególnie pomocny jest jego list do Giedroycia z czerwca 1954 (Listy, s. 173-174). Tłumaczy w nim, dlaczego, pomimo próśb redaktora, nie chce napisać o problemie pisarzy i stalinizmu w Polsce. Na podstawie pierwszych słów tego listu można by wywnioskować, że to milczenie spowodowane jest niczym więcej jak po prostu eksploatacją przez Miłosza emigracyjnego „luksusu moralnego”, pozwalającego na niewłączanie się w kwestie polityczne (który to luksus jest nieosiągalny dla pisarzy krajowych). Jeżeli poprzestaniemy na tym, z łatwością moglibyśmy podejrzewać przyszłego noblistę o pójście na łatwiznę, amoralną eksploatację emigracyjnej pozycji, niemal zdradę wobec świata intelektualistów antystalinowskich za żelazną kurtyną. Nic bardziej błędnego, niż właśnie taka interpretacja postawy Miłosza. Powiedział on bowiem w swoim liście o wiele więcej.

Kolejne akapity listu naświetlają jego prawdziwą postawę. Miłosz pisze:

Nie widzę powodu, dla którego miałbym wyrzekać się tego luksusu [nie mówienia o polityce], kiedy chodzi o aurę inną, właściwą pewnym środowiskom zachodnim, a zapowiadaną przez Orwella.

Rozumiemy tę orwellowską ,inną aurę" na Zachodzie jako „ukłon” w stronę niektórych antykomunistycznych środowisk zimnowojennych, z którymi Miłosz nie chciał mieć do czynienia. Odbierał tę atmosferę jako odwrotną stronę medalu propagandy uprawianej w obozie sowieckim. W dalszym ciągu swego listu odnosi się do „automatyzmów sytuacji”, czyli pewnych wyrobionych, obiegowych sądów, które „rozleniwiają” racjonalny ogląd i które są „mrugnięciami” do pewnych wyższych, generalizujących, upraszczających koncepcji, od których Miłosz wycierpiał ,zarówno w Polsce jak i za granicą”, w związku z tym jest na te rzeczy „wrażliwy”.

Pisze dalej, że brak jego zgody na to, aby problemy świata rozwiązywać stwierdzeniem ,świat tak już jest urządzony”, jest wystarczającym powodem, aby zabrać głos w debacie publicznej. Według Miłosza, to wcale niemało:

Jednak niezgoda na „urządzenie świata” jest istotną funkcją każdego pisarza i nie tak znowu chimeryczną. W sensie politycznej strategii polscy humaniści i arianie XVI wieku znaczyli mało, ale ich dziedzictwem żyjemy do dziś.

\footnotetext{
${ }^{88}$ M. Kornat, Między literatura a polityka, s. 35-37.

${ }^{89}$ Fragment tego listu przytacza M. Kornat; zob.: Między literatura a polityką, s. 38.
} 
Miłosz podaje tu jako wzór wyznawców odłamu chrześcijaństwa w dobie Reformacji ${ }^{90}$, których myśl, choć pragmatycznie nic nie wskórała, to jednak zagwarantowała sobie stałe miejsce w panteonie cywilizacji. Dla Miłosza, jedynym powodem przerwania milczenia w kwestiach polityki jest chęć przełamania konformizmu w ocenie rzeczywistości i obiegowych koncepcji o niej. W tym sensie, nie jest to kompromis ideologiczny, lecz metafizyczny, bowiem oceny, które kształtują świat nierzadko wypaczają jego prawdziwą, ontologiczną naturę, przez stosowanie automatyzmów i uproszczeń.

Tutaj nie chodzi więc ani o wygodnictwo, o amoralną obojętność emigranta, ani o zdradę wobec etycznego nakazu krzyku, gdy dzieje się zło. Chodzi o diametralnie inne, niż panujące w epoce zimnej wojny rozumienie, czym był termin zaangażowanie. Engagement Miłosza polegał na próbie znalezienia odpowiedniego języka, aby uszanować metafizyczną integralność i wewnętrzną spójność każdej jednostki, każdego obiektu, każdego zjawiska, ale także skomplikowanych procesów ideologicznych, egzystencjalnych i filozoficznych, których świadkiem była tamta epoka. I ta właśnie próba metafizycznego określenia natury świata, prądów idei, ludzi, przedmiotów, owoców, drzew, była tym, co Miłoszowi nakazywało pisać. Ta walka o uchwycenie własnej autentyczności i ontologicznej istoty opisywanych zjawisk uwidacznia się nie tylko w jego poezji, ale także esejach, włączając w to Zniewolony umyst.

Bezpośredni związek między stylem i retoryką, a esencją i treścią, nie był bynajmniej wymysłem piewców socrealizmu, lecz stałą od wieków zasadą literatury i sztuki. Treści, które się wyraża mają bezpośredni związek z formą, którą się operuje. Szczęściem dla sztuki Miłosza było jego wyczulenie na kwestię smaku i na dobór słów do opisu rzeczywistości. Czas zimnowojenny nie sprzyjał takim postawom, domagając się opisu świata w zgodzie z wykoncypowanym przez Biblię „tak-tak”, „nie-nie”, którego tak pełna była retoryka rutynowych zimnowojennych artykułów.

To właśnie ta sama uwaga wobec świata, która uczyniła Miłosza wybitnym poetą, stała za dbałością o precyzję słowa i tonu w jego artykułach i esejach: „Jesteśmy zależni od języka, jakim rozporządzamy" pisze w rozdziale o Autentyczności w Abecadle ${ }^{91}$. Poszukiwanie własnej autentyczności i troska o wyrażenie autentyczności innych, dla pisarza-metafizyka, którym był Miłosz, miała bezpośredni związek z retoryką i językiem. Tutaj także należy szukać przyczyn niezgody Miłosza na uproszczenie, uładzenie i generalizacje, stosowane zgodnie z pragmatyką polityczną, ale zabójcze dla rzeczywistości, która Miłosza fascynuje i uwodzi jako poetę.

Engagement Czesława Miłosza wobec rzeczywistości nie wynikał z miłości do literatury, lecz do samej rzeczywistości. Postawa Miłosza nie wynikała z zimnego nastawienia estety wykuwającego majstersztyki w swym laboratorium twórczości, lecz z miłości do otaczającego go, nieprawdopodobnego, nieokiełznanego, zapierającego dech w piersiach świata. Uczuciem tym obejmował także bliskich sobie ludzi. W pierwszych latach emigracji, pomimo swego rozdarcia, zawsze starał się nie ranić ludzkich uczuć. W swoim liście do Mertona mówi: „W rzeczywistości ja tych ludzi, przeciw którym zwróciłem mój gniew, kocham o wiele bardziej, niż to pokazałem"92.

${ }^{90}$ Może dlatego określał Zniewolony umyst jako traktat teologiczny w dobie Reformacji („Dla mnie produkt uboczny, niby traktat teologiczny poety z czasów reformacji”; Rok myśliwego, s. 84), zaś w Abecadle rozprawiał o Bluźnierstwie.

${ }_{91}$ Cz. Miłosz, Abecadto, s. 56.

${ }^{92}$ List z 17 stycznia 1959 przytoczony w: A. Bikont i J. Szczęsna, Lawina i kamienie, s. 232. 
W 1951 r., w „Liście do rodaków” pisał: „moje serce jest gorące i jest w nim wielka miłość do ludzi" "93. Tam też słowa „Prawda i Sprawiedliwość” — te same, którymi zakończył tomik Ocalenie - uznał za przewodnie i najważniejsze dla siebie.

\section{Trudna droga do Prawdy i Autentyczności}

Jak zauważa Miłosz, podstawowym problemem w próbach dotarcia do własnej autentyczności jest opanowanie zewnętrzności. W ustępie Abecadta poświęconym Wmówieniu pisze:

Nasza zdolność do wmawiania w siebie wydaje się nieograniczona. Przekonujemy siebie samych, a też dajemy się przekonać innym. I w naszej wewnętrznej kuchni jest tyle chytrych sposobów przyrządzania potraw, że nie bardzo umiemy się rozeznać i rozróżnić, co autentyczne, a co nie. Autentyczne, a więc własne? Gdzież tam, najbardziej własne też może być zmyślone i dajemy się wciągnąć, godząc się na ułudność przynęty. [...] I rzeczywiście - granica między przekonywaniem siebie i wewnętrzną zgodą na opinie innych, czyli na propagandę, jest płynna. Przygnębiające, człowiek jako istota bez ustanku uwikłana $\mathrm{w}$ innych, a równocześnie tęskniąca do wydobycia się $\mathrm{z}$ tak uzbieranych pokładów fałszu ${ }^{94}$.

W swoich rozmowach z A. Fiutem Miłosz wyjawia, że jego „stały problem” to „chęć żeby nie wydać się kimś innym, niż się jest. To, muszę przyznać, gnębiło mnie całe życie i nadal gnębi. [...] Dla mnie jest wysoce żenujące, kiedy ze mnie robią poetę patriotę, barda, wieszcza, bo jakoś do tej roli nie byłem przygotowany". Przez całe życie Miłosz odżegnuje się od bycia ,,autorytetem moralnym”, co było dla niego „trochę humorystyczne”, „na pewno [...] nie prawdziwe”, „bardzo żenujące” i próbuje przekonać, że tylko „szczególne zbiegi okoliczności” zdecydowały, że się zbytnio nie „utytłał” w ciągu swojego życia, a nie jakaś szczególna nieskazitelna postawa moral$\mathrm{na}^{95}$. Mówi Miłosz, że wbrew tym, którzy „tropią jego hardość nonkonformisty”, skłonny byłby brać stronę swoich wrogów, „bo grzeczny chłopczyk i harcerzyk dość mocno tkwi we mnie"96. Dodaje, że przeciwko jego „rzekomej sile” przemawia „skłonność do dzielenia włosa na czworo i do delectatio morosa”, masochistycznego rozpamiętywania własnych grzechów.

Jednak to właśnie te cechy, które sam odczuwa jako wady, umożliwiły Miłoszowi tak wielkie zaangażowanie się w opisywaną rzeczywistość. Być może zasługuje on na „miano człowieka obsesji i uprzedzeń”, ${ }^{97}$, jednak to właśnie te obsesje i uprzedzenia stoją za jego „nieuładzonym” myśleniem oraz ciągłą refleksją nad sobą i innymi, bez których nie powstałyby jego dzieła:

Opowiadając o moim dwudziestym wieku, staram się być uczciwy, w czym pomagają mi moje wady, nie zalety. Zawsze trudno mi było wybierać, opowiadać się kategorycznie po którejś stronie, trwać uparcie przy swoich poglądach. Godząc się na swoje miejsce, zawsze wobec moich współczesnych zewnętrzne, próbowałem wczuwać się w przeciwne sobie racje. [...] Pracujemy na rzecz prawdy o czasie naszego życia, nawet, jeżeli jego obrazy, pochodzące od różnych ludzi, nie są ze sobą zgodne. Istniejemy

${ }^{93}$ Cz. Miłosz, List „Drodzy Rodacy”; cyt. za: J. Giedroyc, Cz. Miłosz, Listy 1952-1963, s. 735.

${ }^{94}$ Cz. Miłosz, Abecadto, s. 343-344.

95 A. Fiut, Czestawa Miłosza autoportret, s. 333-334, 337-339.

${ }^{96}$ Cz. Miłosz, Abecadło, s. 229.

${ }^{97}$ Tamże, s. 332. 
jako odrębne byty, ale zarazem każdy z nas występuje jako medium poruszane bliżej nieznaną siłą, niby prądem wielkiej rzeki, przez co upodabniamy się do siebie we wspólnym stylu czy formie. Prawda o nas będzie przypominać mozaikę ułożoną z kamyków różnej ceny i barwy ${ }^{98}$.

Dzielenie włosa na czworo, obsesyjność, podejrzliwość, upartość, ostrożność, to wszystko stanowi współrzędne metafizyczno-etycznej przestrzeni, z której tworzył Miłosz. Pomimo swych „wad” i wiecznej „zewnętrzności” wobec sobie współczesnych, niewolny był Miłosz, jak sam przyznaje, od pułapki „Wmówienia”. W wywiadzie, który przeprowadziłam z Miłoszem w grudniu 2003 r., na pytanie czy wierzy w siłę pojedynczego intelektu do obalenia obiegowych schematów, Miłosz odpowiadał, przerywając swe rozważania wybuchami spontanicznego śmiechu:

[...] te narzucane obiegowe pojęcia nie są, powiedzmy, mniej obce pojęciu Prawdy niż poszukiwania indywidualne. To znaczy, wpływy na myśl indywidualną myśli zbiorowej są bardzo podstępne... [śmiech] Chcemy być bardzo niezależni, ale nie bardzo nam się to udaje... [...] No, więc, chcę wierzyć w tę możliwość postawy niezależnej, bo mój $\mathrm{w}$ tym interes żeby w to wierzyć, ale tak naprawdę to... nie bardzo wierzę [śmiech] ${ }^{99}$.

Cieszy to, że pod koniec swego życia, głęboka świadomość o trudzie docierania do własnej autentyczności i do prawdy o innych, była przyjmowana przez Miłosza nie $\mathrm{z}$ dramatyczną świadomością porażki, lecz z autoironicznym (i radosnym) sceptycyzmem. Prawda o świecie i ludziach jest złożeniem pojedynczych prawd o jednostkach i fenomenach, chociaż te nie są sobie równe: „Prawda o nas będzie przypominać mozaikę ułożoną z kamyków różnej ceny i barwy". Pod koniec swego życia, nie oceniał samego siebie zbyt dobrze, w porównaniu do innych kamyków swego czasu, kolejny raz dając dowód swej pokory i swej twardości w myśleniu o sobie.

A przecież walka o „substancję i autonomię” charakteryzowała całe życie Miłosza, zarówno w jego starciach z polskim środowiskiem literackim i emigracyjnym, włączając w to „Kulturę”, jak i z wielkimi machinami propagandy kulturalnej, jak Kongres Wolności Kultury. W Zniewolonym umyśle zadawał kluczowe pytanie o to, jaki typ wolności może zaoferować Zachód, bowiem to właśnie w zderzeniu Zachodu ze Wschodem chodziło Miłoszowi o głębokie pytania i o konieczność znalezienia na nie odpowiedzi.

Aby wyrazić nową substancję rzeczywistości XX w. potrzeba było nowego języka, $\mathrm{n}$ a z y w a j ą c e g o, ostrożnego, wyważonego, naświetlającego, sugerującego. I także tutaj, w kwestii ściśle związanej ze s ty l e m, znajdujemy przyczynę niezgody Miłosza na wszelką sztucznie wykoncypowaną retorykę, włączając w to język zimnowojenny. Język Miłosza uwidacznia poszanowanie dla wewnętrznej spójności opisywanych zjawisk, gdzie obiekt studium jest celem samym w sobie. Ta sama pokora była podstawą szacunku dla prawdy innych, chęci niezranienia i stania na straży indywidualnych osób i pojedynczych pojęć (uczynił z tego niemal osobny gatunek literacki w Abecadle). W zaangażowaniu i miłości wobec świata, pochylał się nad jego metafizyczną całością i starał się uchwycić autentyczność jego niejednoznaczności.

Uczciwość argumentacji racjonalnej, szacunek dla przeciwnika, zaangażowanie wobec prawdy innych, próba sprawiedliwego oddania całości: wszystkie te „wierności”

\footnotetext{
98 Tamże, s. 249.

${ }^{99}$ Cz. Miłosz, Chcę wierzyć, wywiad O. Glondys, Zeszyty Literackie 2006 nr 94, s. 112.
} 
Miłosza były „wiernościami” starym przyjaciołom. Własne półcienie i zachodzące na siebie dyskursy rozmaitych przestrzeni moralnych, które Miłosz w samym sobie odczuwał jako sprzeczności, były po prostu wiernym przełożeniem skomplikowanej prawdy świata zewnętrznego.

W swym trwaniu po stronie człowieka XX w., Miłosz pochylał się nad nim jako nad bytem miotanym Historią i własną niedoskonałością, jako ofiarą swej wybrakowanej empiryki i formalnej dialektyki. Człowiek dla Miłosza był celem i podmiotem, nie zaś, jak dla wszelkich ludzi o mentalności zimnowojennej, uproszczonym i pragmatycznym narzędziem własnej wizji świata. Miłosz, który obrał jako przewodnie dla siebie idee Prawdy i Sprawiedliwości, rozumiał je zawsze jako drogi wiodące ku rzeczywistemu Człowiekowi.

\section{THE CONGRESS FOR CULTURAL FREEDOM AND THE FREEDOM OF CZESŁAW MILOSZ: A REFLECTION ON INVOLVEMENT AND WAY TO THE TRUTH IN THE AGE OF COLD WAR}

The article explores in detail the poet's cooperation with CCF, presenting also the endeavours in favour of retaining his own autonomy in the presence of that institution, as well as Miłosz's every action in order to prevent himself from being exploited by the Congress. The Author uses archival documentation.

KEY WORDS: Cz. Miłosz; Congress for Cultural Freedom; Cold War. 